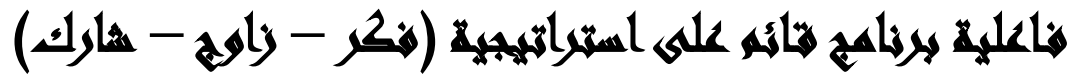

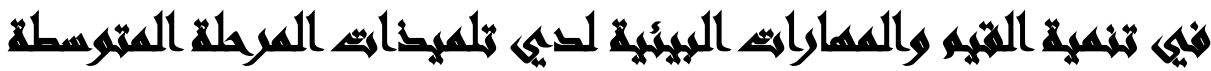

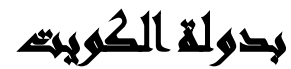

\author{
$[1 \cdot]$

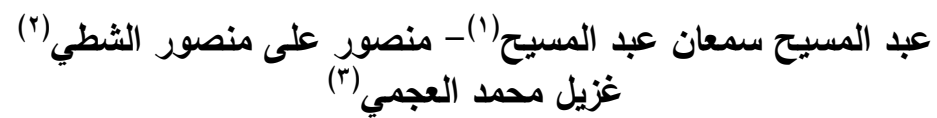 \\ () معهد الدراسات والبحوث البيئية، جامعة عين شمس r r) مركز الاستثارات السلوكية \\ والعائلية، الكويت ؟) وزارة التربية، الكويت اليته
}

\section{المستخلصى}

هدف البحث إلى تتمية القيم والمهارات البيئية لدى تلميذات المرحلة المتوسطة من خلا

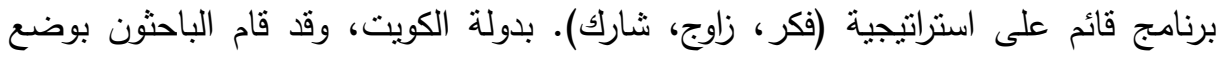

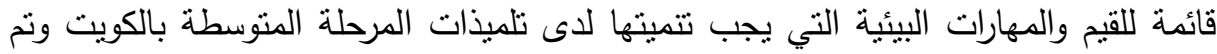

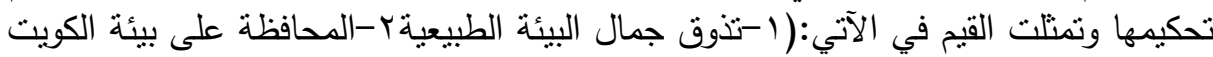

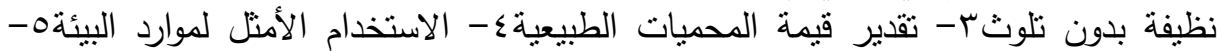

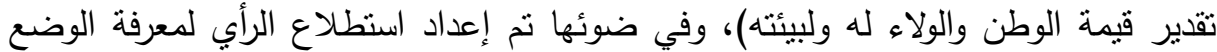

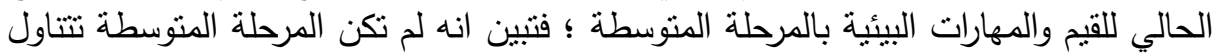
القيم والمهارات البيئية بالقدر الكافي الذي ينمي هذه القيم والمهارات البيئية للتلميذات من خلال

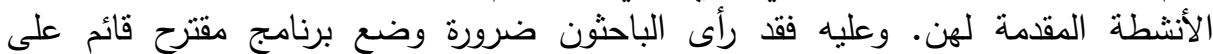

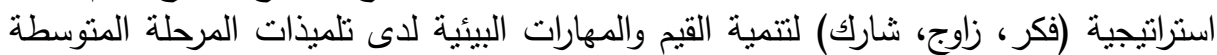

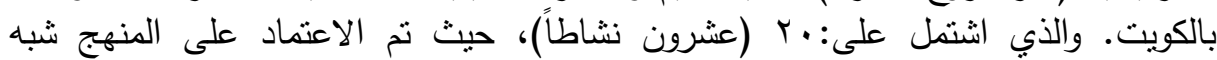

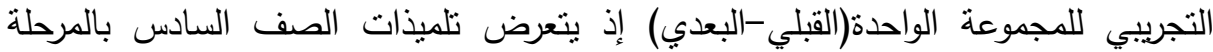

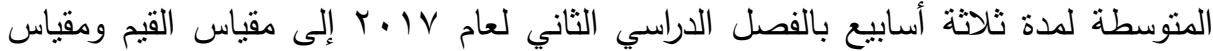

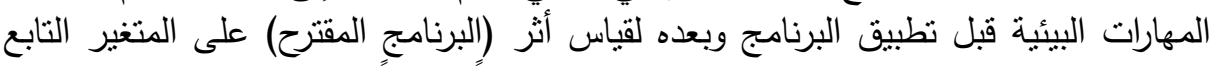

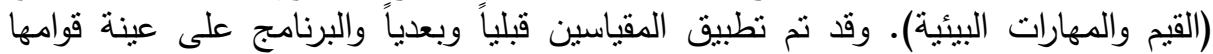

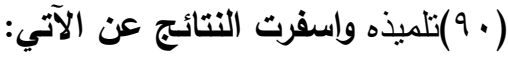

توجد فروق ذات دلالة إحصائية بين متوسط درجات التئ التلميذات في التطبيق القبلي

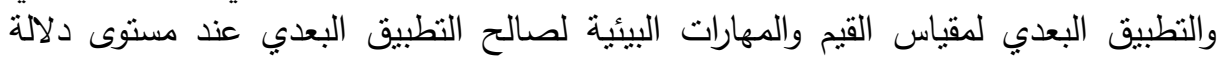

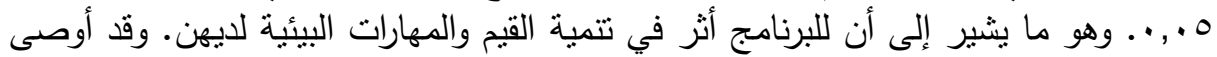

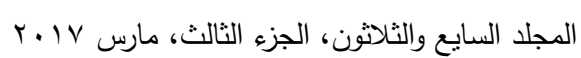


البحث بضرورة تطبيق البرنامج من خلال وزارة التربية بالكويت لتتمية القيم والمهارات البيئية

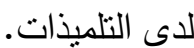

\section{ranodl}

تساعد التربية على تتمية القيم التي شغلت اهتمام العلماء والباحثين حيث تتبع أهمية

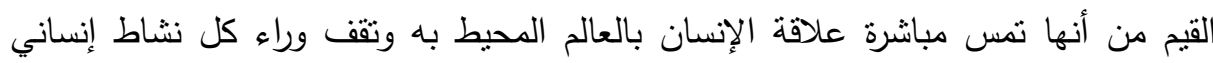
يؤديه الفرد في تفاعله مع البيئة المادية والاجتماعية، وأن القيم تمثل الموجهات العامة لسلوك بهات بهات الإنسان، كما تؤثر بصورة حاسمة في تكوين معتقدات واتجاهات ونظرة الإنسان إلى العالم

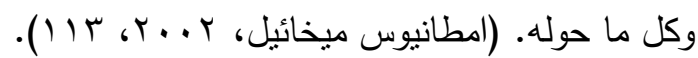

فالتعليم بمدارس المرحلة المتوسطة بالكويت يعد من إحدى المؤسسات التربوية والتعليمية

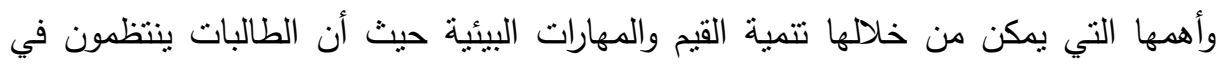
فصول دراسية ويتلقون العلم ويمارسون عمليات التعلم، لذا يجب أن تهنم جميع المناهج الدراسية والبرامج والأنشطة التعليمية بإبراز المشكلات البيئية على جميع المستويات المحلية والقومية والعالمية.

وانطلاقا من كون القيم البيئية أحد أبرز المرتكزات التي تستهدفها التربية البيئية للارتقاء بمستوى مهارات وسلوكيات الطلاب نحو البيئة في صورتها الكلية والإحساس بمشكلاتها، وإدراك المسئولية الأخلاقية لحمايتها من الانتهاك وتكوين الاتجاهات نحو مختلف قضاياها. وطبقاً لذلك فان قيم الفرد ومهاراته تتكون نتيجة احتكاكه بمواقف خارجية منباينة تؤثز في الته سلوكه نحو بيئته بحيث ينتهي به الأمر إلى تكوين اتجاهات، ومواقف إزاء القضايا الاجتماعية ومشاكلها المختلفة بطريقة ما، حيث نتأثز تلك الاتجاهات والمواقف، سلباً أو إيجاباً بالقيم

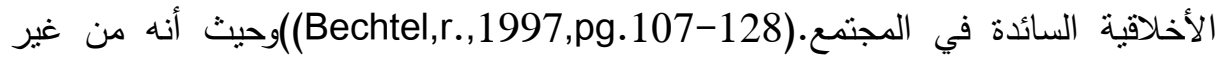
المستطاع حل مشكلاتتا البيئية بجهود ارتجالية، وإنما عن طريق جهود علمية جادة تقوم على الثى

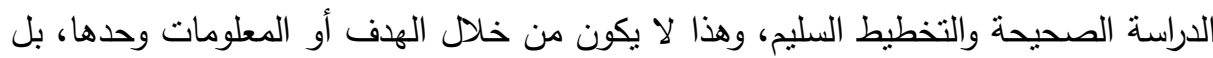
بتأثنر ما يكتسبه الإنسان من مهارات واتجاهات وما يستخدمه من أسلوب تفكير في تفاعله مع دع

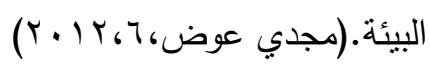


فالمرحلة المتوسطة ينضج فيها التلميذات عقليًا ووجدانيًا بما يؤهلهم لاستيعاب حقيقي

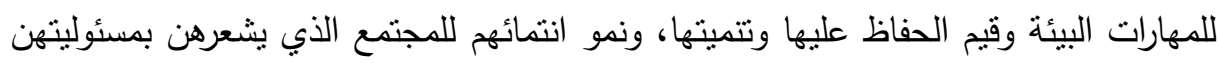
نحو البيئة بما يجعلهم ملتزمين بالسلوك البيئي الصحيح.

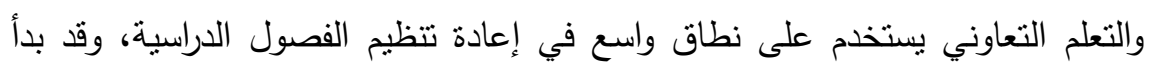
كوسيلة لتحسين العلاقات الإنسانية بين الطلاب، وتزويدهم بسبل التفاعل وتتمية المهارات الاجتماعية لايهم، ولقد ساهم التعلم التعاوني في تغيير المناخ في الفصول الدراسية من لئنس

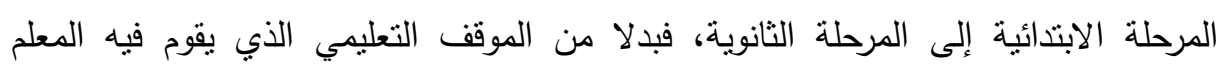

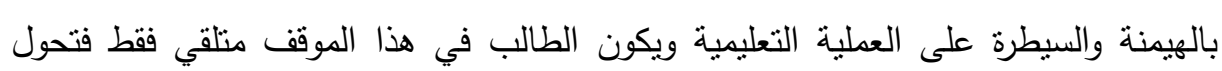

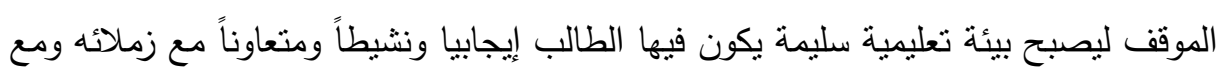
المعلم في العملية التعليمية. (Platte, Stephen , 1991, p326-28) وتمثل إستراتيجية (فكر، زاوج، شارك) أحد الاستراتيجيات الهامة في التربية، فنحن اليوم

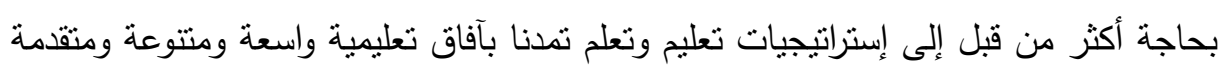

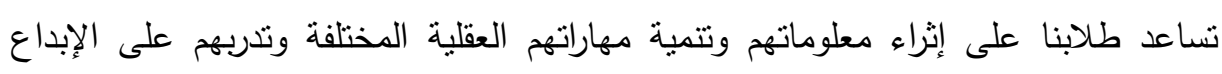
وإنتاج الجديد والمختلف، وهذا يدعمه ويساعد في تحقيقه وجود معلم يعطي طلابه فرصة

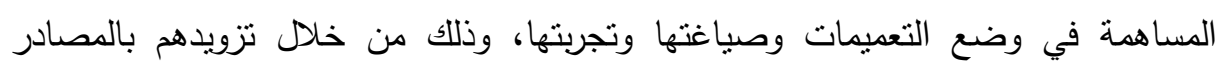
المناسبة وإثارة اهتماماتهم وحملهم على الاستغراق في التفكير الإبداعي وقيادتهم نحو الإنتاج

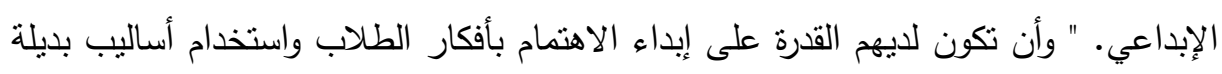

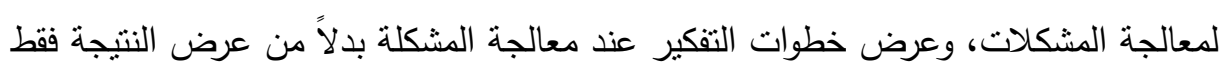
". مما يدفعهم نحو نطوير نماذج التفكير والقدرة على تقييم نتائج التعلم بشكل فعال. (سليم

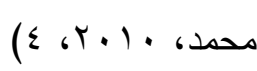

ويقوم البحث الحالي على تبني إستراتيجية (فكر - زاوج - شارك) كإستراتيجية تعليمية،

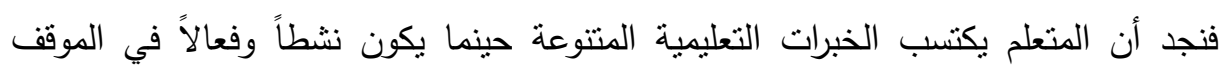

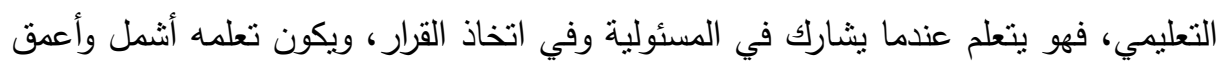

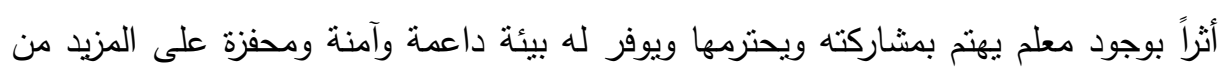

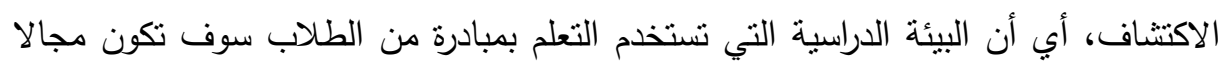

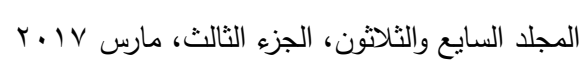


واسعا للنشاط كمجوعات عمل صغيرة لطلاب يعملون في مشاريع أو أنشطة مفيدة في العملية

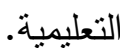

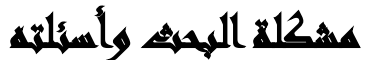

ولما كان الحفاظ على البيئة والمساهمة الإيجابية في حل المشكلات البيئية مرهون بدرجة

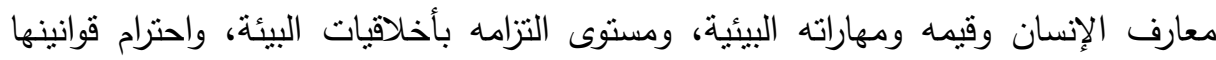
والدفاع عن قضاياها وحماية مواردها من الاتتهاك والاستتزاف، فإنه لابد من التوجه نحو الإنسان تربية وإعداداً يتوافق مع تحقيق التتمية من خلال الحفاظ على التوازن البيئي.

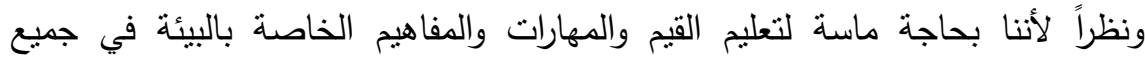
المراحل الدراسية، بدءاً من المراحل الأولى ومروراً بجميع المراحل التعليمية، حيث أنثار

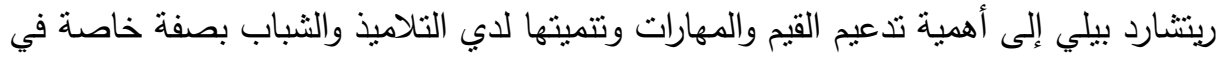
Richard Baily, , ) مرحلة التكوين والإعداد، فهم لا يصبحون مواطنين صالحين بالصدفة (2000,pg. 157

واستجابة لأهداف المرحلة المتوسطة بالكويت والتي تسعي إلى تكوين اتجاه منوازن نحو الكون والحياة وتتمية القدرة على التكيف السليم معها، كما تسعي هذه المرحلة إلى إكساب التلاميذ قيم ومهارات العمل من بذل للجهد، ودقة في الأداء، وقدرة على العمل الجماعي التعاوني واستتادا لنتائج الدراسات السابقة والتي أظهرت قلة الاهتمام والقصور في تتاول البعد

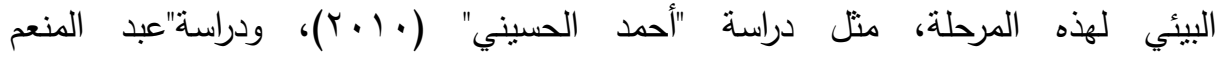
درويش"( T . . Y)،كان هناك الحاجة إلى تتمية القيم والمهارات البيئية. كذلك ما أثشارت إليه

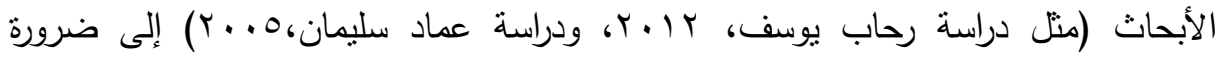
الاهتمام بالبيئة بين الناس وخاصة التلاميذ. وعلى هذا فبينما تبدو برامج التربية البيئية في

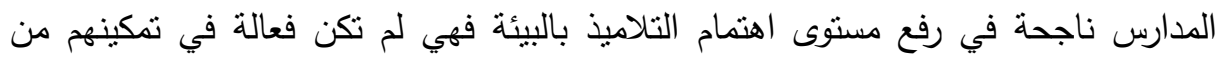
التعبير عن هذا الاهتمام في شكل قيم وممارسات تدعم استدامة البيئة بمواردها الطبيعية. 
وعلى ما أظهرته الدراسات والبحوث منل دراسة كل من (آمنة خميس، ع . . ب)، ودراسة

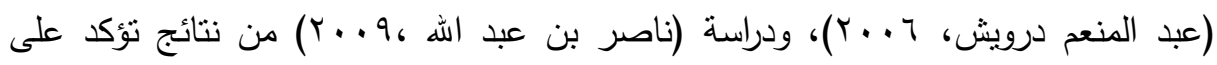
ضرورة استخدام التعلم التعاوني في تتمية القيم والاتجاهات والمهارات البيئية والمسئولية البيئية. كذللك قام الباحثون بدراسة استطلاعية من خلال مقابلة مع بعض المعلمين (وسؤالهم عن فئن

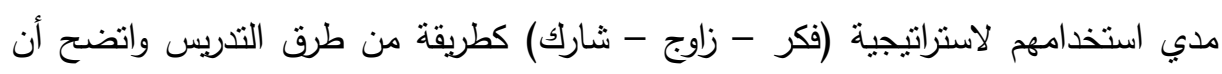

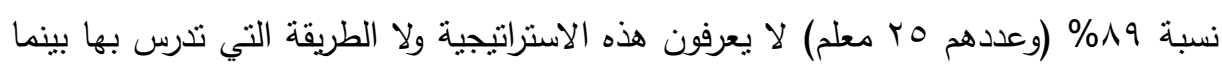

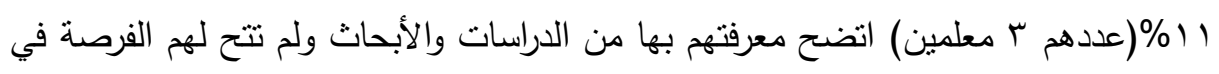
استخدامها.

كما قام الباحثون كذلك بقياس القيم والمهارات البيئية ونم الاستعانة بمقياس القيم البيئية

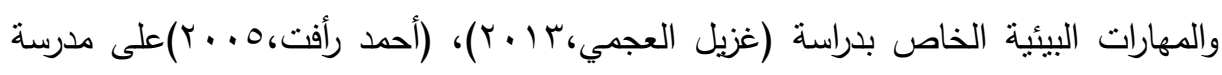

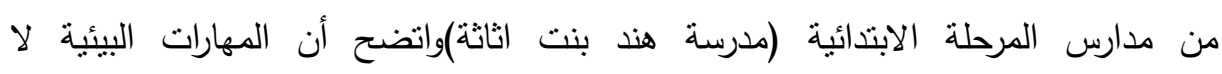

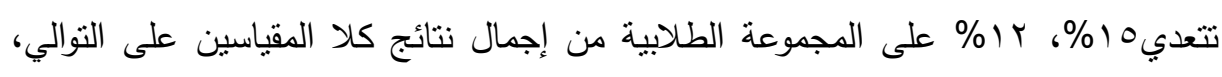
من نسب المهارات والقيم المقاسة.

\section{أسمئل الهمهي}

وفي محاولة للتصدي لهذه المشكلة حاول البحث الإجابة عن السؤال الرئيس الآتي:

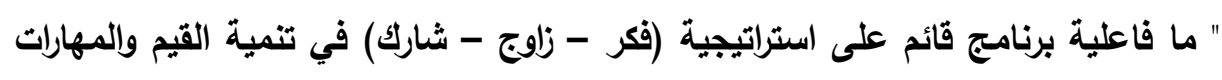

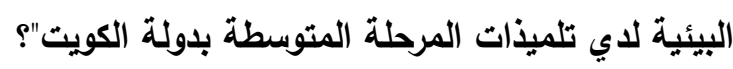

ويتفرع عن هذا السؤال الأسئلة الفرعية التالية:

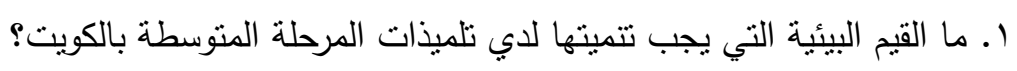

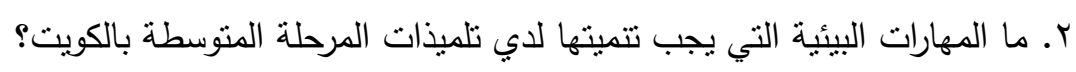

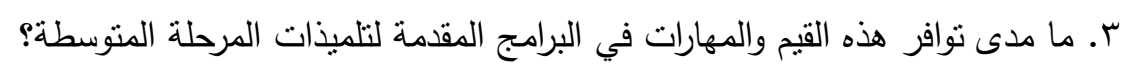

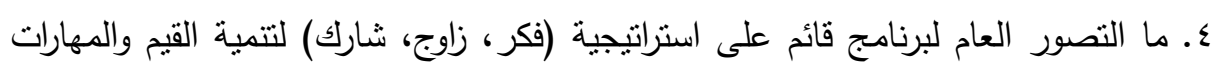
البيئية لدى تلميذات المرحلة المنوسطة بالكويت؟

ه. ما فاعلية البرنامج المقترح في تتمية القيم والمهارات البيئية لدي تلميذات المرحلة المتوسطة الكئة بالكويت؟ 


\section{همبهن الهمبه}

هدف البحث: إلى تتمية القيم والمهارات البيئية لدى التلميذات بالمرحلة المتوسطة بدولة الكويت من خلال البرنامج المقترح والقائم على استراتيجية (فكر، زاوج، شارك).

\section{أهمية المهمش}

قد تقيد نتائج البحث الحالي كلاً من: (1) القائمين على تطوير وتخطيط العملية التعليمية بوزارة التربية، لتدعيم القيم والمهارات البيئية في مرحلة التعليم المتوسط بما يتلائم مع النطور في أساليب واستراتيجيات التعليم النشطة والمنطورة.

r) المدرسة-والمعلمين: من خلال تقديم الأنشطة البيئية المختلفة المتضمنة في البرنامج للمعلمين في تتمية القيم والمهارات البيئية لاى التلميذات، للارتقاء بدور المدرسة في لي لئه

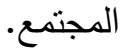
r) الباحثون من خلال ما يقدمه البحث من أدوات (مقياسي القيم البيئية والمهارات البيئية) وبرنامج مقترح قد بساعدهم في إعداد بحوث مماثلة. ع) تقديم تصميم تعليمي لبرنامج بيئي باستخدام استراتيجية (فكر، زاوج، شارك).

\section{هزوض المهنيش}

حاول البحث الحالي التحقق من صحة الفروض التالية:

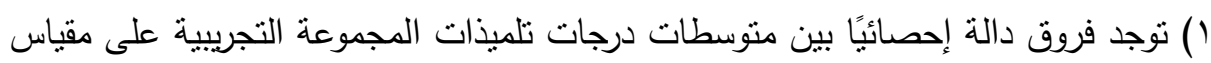
القيم البيئية قبل وبعد تدريس البرنامج المقترح لصالح التطبيق البعدي. r) توجد فروق دالة إحصائيًا بين متوسطات درجات تلميذات المجموعة التجريبية على مقياس المهارات البيئية قبل وبعد تدريس البرنامج المقترح لصالح التطبيق البعدي.

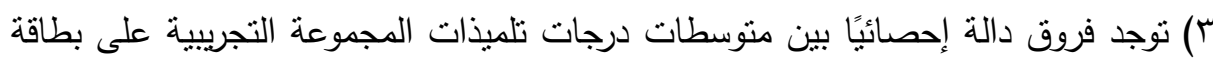
ملاحظة الأداء قبل وبعد تدريس البرنامج المقترح لصالح التطبيق البعدي. 


\section{مiهمج الهيهA}

المنهج شبه التجريبي: حيث ينم الاعتماد على التصميم التجريبي للمجموعة الواحدة(القبليالبعدي) إذ ينعرض ثلميذات المرحلة المتوسطة بالصف السادس (مجموعة البحث) إلى مقياس البراس

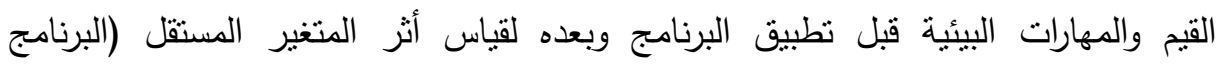
المتترح) على المتغير النابع (القيم والمهارات البيئية).

\section{مشوت الهمبه}

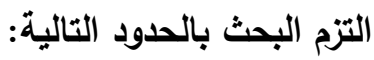

1-الحدود الزمنية: اقتصر تطبيق البرامج المقترح على العام الدراسي بوزارة التربية

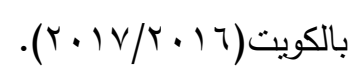

r-الحدود الجغرافية: اقتصر البحث على مدارس ثلميذات المرحلة المتوسطة بالكويت

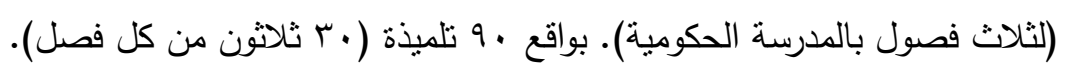

r- الحدود البشرية: نم اختيار مجموعة الدراسة من تلميذات الصف السادس بالمرحلة

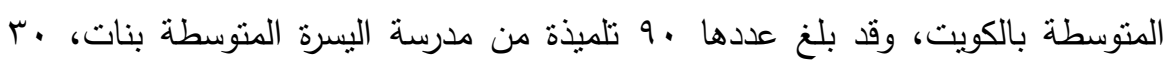
تلميذة من كل فصل لثلاثة فصول بالمدرسة، بإدارة محافظة الاحمدي التعليمية، بدولة

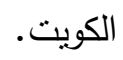

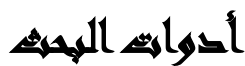

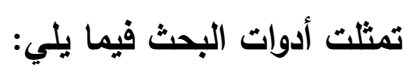

• قائمة للقيم والمهارات البيئية التي يجب تنتميتها لدي تلاميذ المرحلة المتوسطة بالكويت.

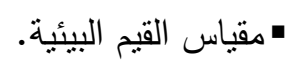

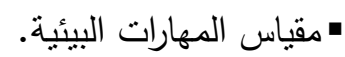

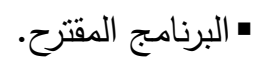




\section{كسطلحاهي الهمبش}

استراتيجية (فكر - زاوج - شارك) Strategy (Think - Pair-Share) نعرف بأنها: أحد الاستراتيجيات التي تؤيد نتويع الندريس والتعلم النشط في آن واحد وتعتمد على لئ استثارة التلاميذ كي يفكروا كلاً على حدة، ثم يشترك كل ثلميذين في مناقشة أفكار كل منهما وذللك من خلال توجيه سؤال يستدعي تفكير التلاميذ، وإعطاءهم الفرصة كي يفكروا على

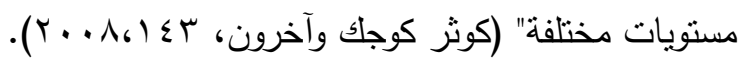

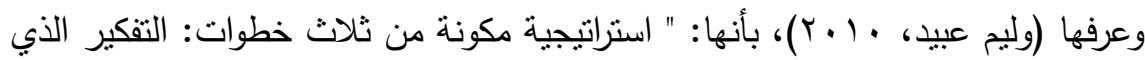
يطرح فيها المعلم مسألة ما ثم شرحه من معلومات المتعلمين ثم الطلب أن يفكر كلاً منهم

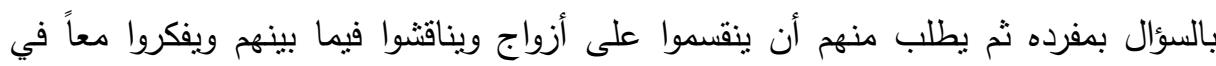

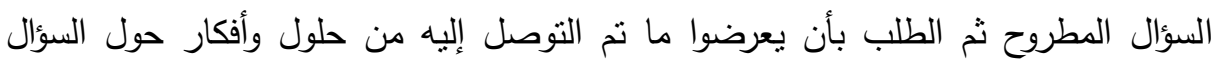

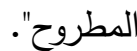

القيم البيئية Environmental values: هي الأحكام العقلية الانفعالية المتعلقة بمكونات البيئة الطبيعية، والإنسانية ذات الصلة المباثرة بعناصر البيئة الطبيعية، الموجهة

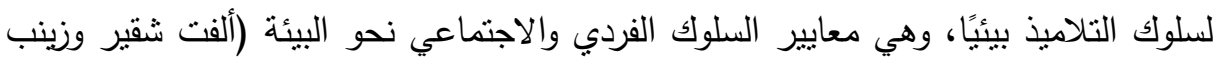

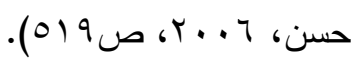

وتم تعريف القيم البيئية بأنها: "الأحكام التي يصدرها الفرد بالتفضيل أو عدم التفضيل إزاء المواضيع البيئية وذلك في ضوء نقييمه وتقديره لهذه المواضيع البيئية، وتتم هذه العملية من خلال التفاعل بين الأفراد بمعارفه وخبراته وبين ممثلي الإطار الفكري الحضاري الذي وني يعيش فيه واكتسب من خلالها هذه الخبرات والمعارف".(عبد اللطيف خليفة، بو 99 (1، 9 ه)

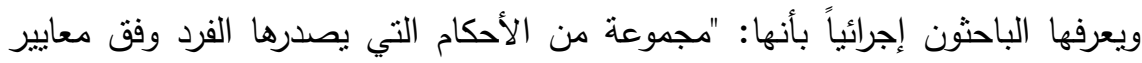

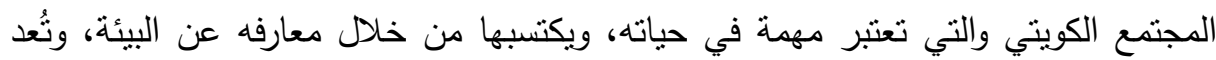

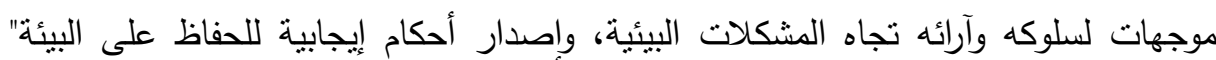
ويعبر عن القيم البيئية في البحث الحالي بمجموع الدرجات التي يحصل عليها تلميذات المرحلة المتوسطة على مقياس القيم البيئية المعد لذلك. 
المهارات البيئية Environmental skills: "هي القيام بعمل معين يرتبط بالبيئة في

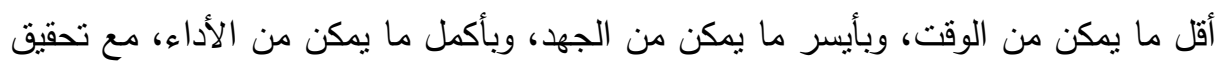

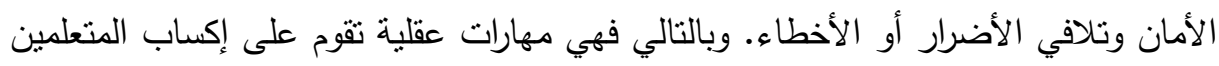

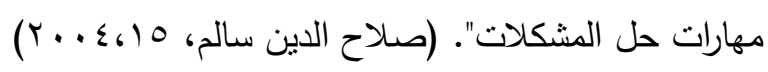

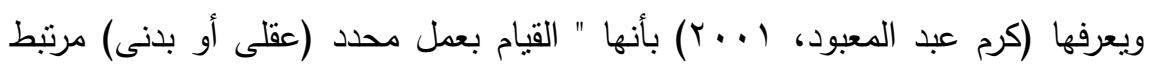

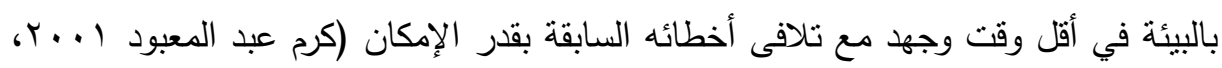

وتم تعريف المهارات البيئة إجرائيا بالبحث الحالي بأنها " مجموعة من النشاطات البيئية

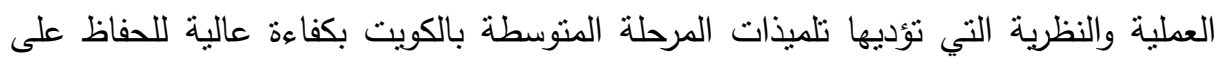

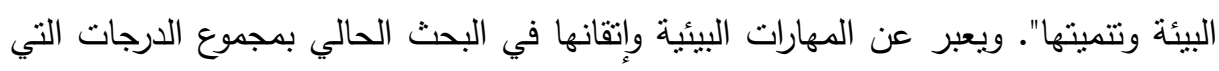
يحصل عليها تلميذات المرحلة المتوسطة على مقياس المهارات البيئية المعد لذلك.

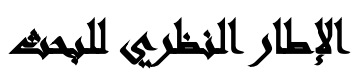

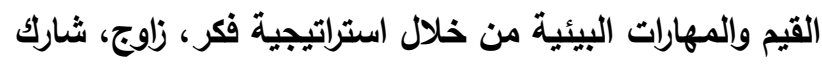

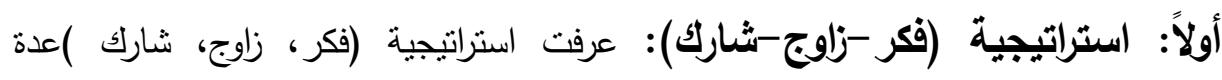

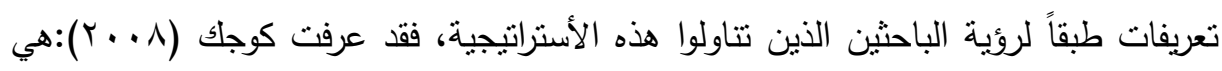

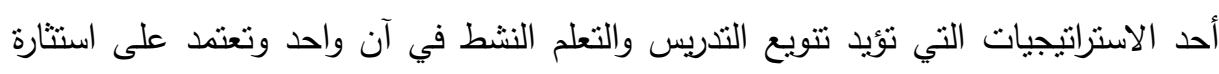

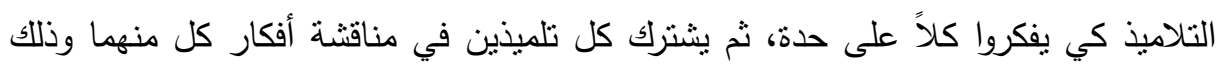

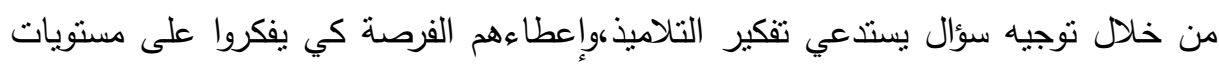

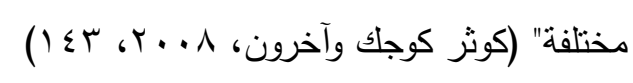

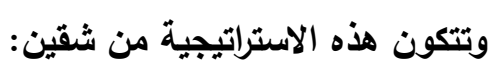

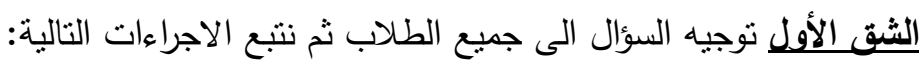

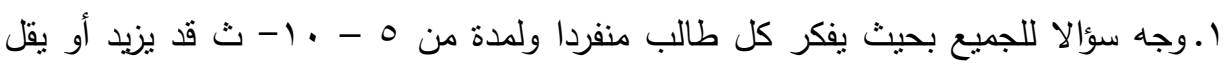
الوقت حسب تقديرات المعلم فقد يحتاج التفكير دقائق. 
r.بعد عملية التفكير الفردي لكل طالب ينتارك كل طالبين معا ويتبادلان مشاركاتهما في الخطوة الأولى ويتفقان على إجابة مشتركة.

r. اختر عشوائيا عدد من الطلاب لتلخيص مناقشتهم أو تقديم حلولهم. إنهاه

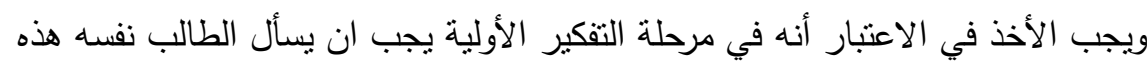
الأسئلة ويمكن ان يساعده المعلم في ذلك إذا اقتضى الأمر كبداية حتى يتدرب على طرئ طريقة التقكير ومن هذه الاسئلة: س - ماهي المعلومات التي احتاجها لحل هذه المسألة ؟ هاله س - ماهي المعلومات التي اعرفها عن هذه المسألة ؟ ماهي

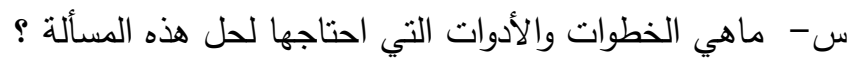
س - ماهي الأسئلة التي احتاجها حتى اسأل زميلي في الخطوة القادواتهة ؟

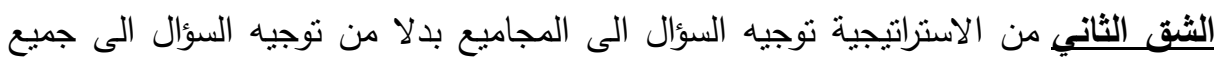
الطلاب، ويوجه السؤال الى المجاميع وتتم الاستراتيجية ضمن جميع أفراد المجموعة المؤلفة تولة من أربعه طلاب.

المراحل التي تمر بها عملية التفكير وفقا لهذه الاستراتيجية:

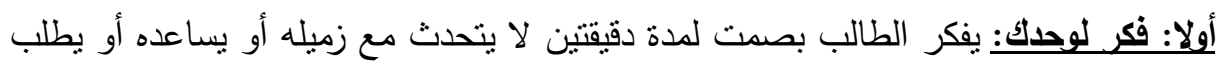
منه ألمساعده أو يرفع يده قد بستخدم الورقه أو القلم. ثانبا: فكر مع زميلك: كل طالب يطرح فكرته الأفضل لزميله الآخر وسبب اختياره لهذه الفكره أو الإجابة لمدة دقيقتين لكل منهما ويتفقان على أجابه واحدة.

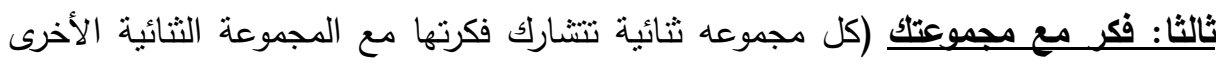
موضحين سبب اختبارهم لهذه الإجابة دقيقتان لكل مجموعه ثنائية)

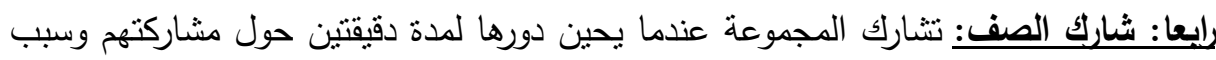
اختيارهم من خلال تعيين متحدث المجموعة وقد يستخدم المعلم استراتيجية الروؤس المرقمة

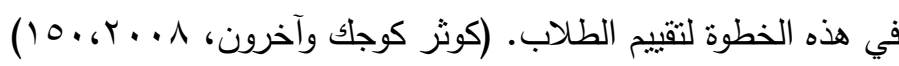




\section{الأسس التي تقوم عليها استراتيجية ( فكر زاوج شارك ) تعتمد هذه الاستراتيجية على عدة

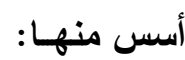

- انشتراك الطلاب في اختيار نظام العمل وقواعده.--إثراك الطلاب في تحديد أهدافهم التعليمية

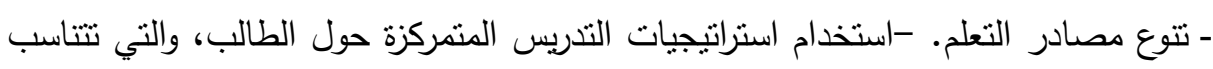

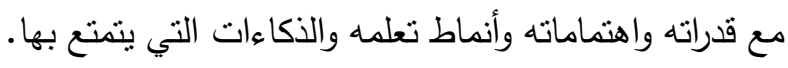

- الاعتماد على تقويم الطلاب لأنفسهم وزملائهم.

- إناحة التواصل في جميع الاتجاهات بين المتعلمين وبين المعلم.

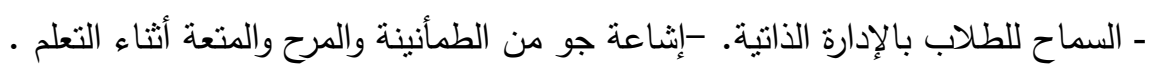

$$
\text { - تعلم كل طالب حسب قدراته. }
$$

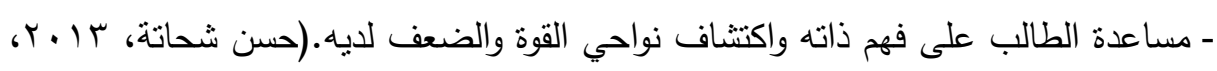

ثانياً القيم البيئية: لقد شكلت القيم بكافة أنواعها على مر العصور إطارًا مرجعيًا يحكم سلوك الفرد والجماعة، ويوجه تصرفاتهم، بالإضافة لكونها تحفظ للمجتمع تجانسه وترابطه.

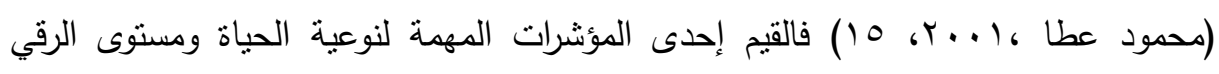

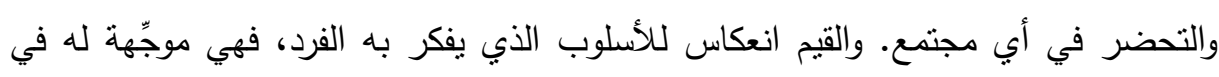

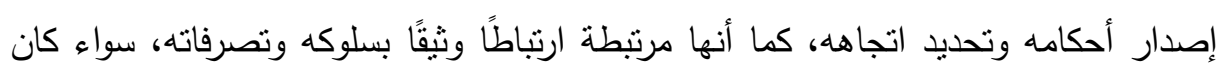

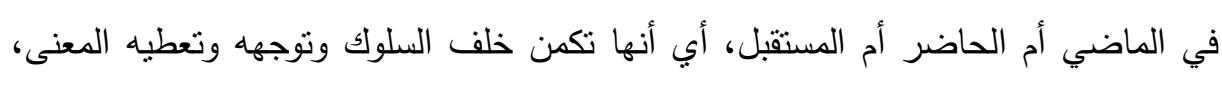

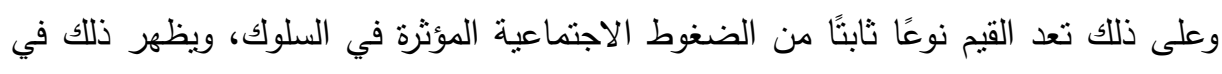

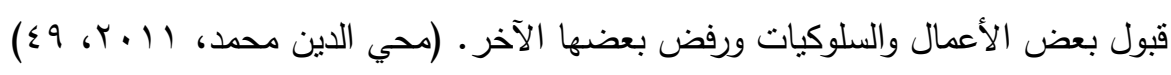

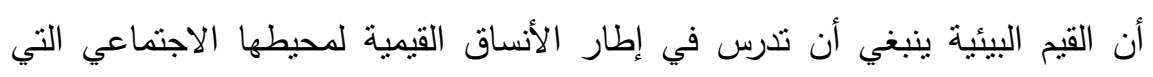

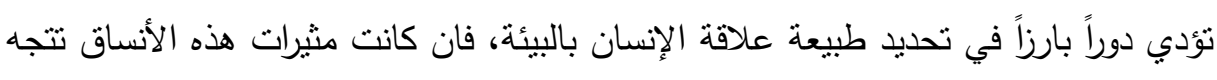

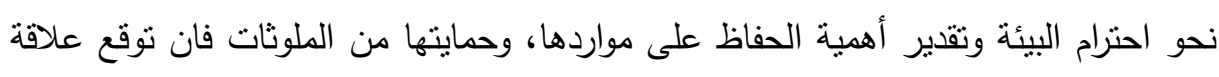

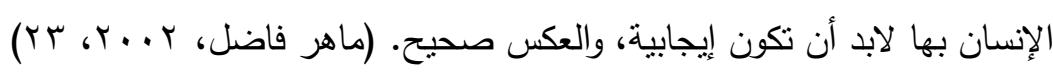

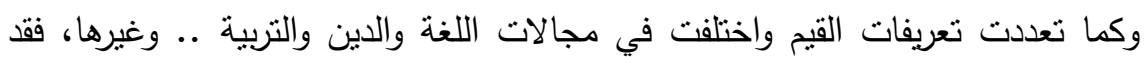

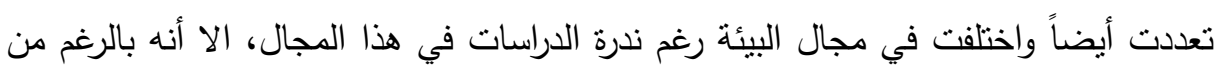

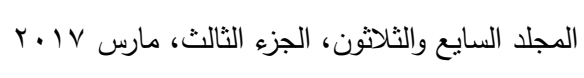


اختلاف وجهات النظر حول مفهوم القيم البيئية، إلا أنه يوجد اتفاق بشكل عام حول ماهية القيم، ويمكن إجمال أوجه الاتفاق هذه فيما يلي: (1) إمكانية التعبير عنها في مواقف معينة، من خلال أحكام ووجهات نظر ومشاعر صاحبها لهاهـا تجاه هذه المواقف.

r) إلزامها للفرد باختيار محدد بين بدائل متعددة، تعبيرًا عما يتبناه الفرد من قيم.

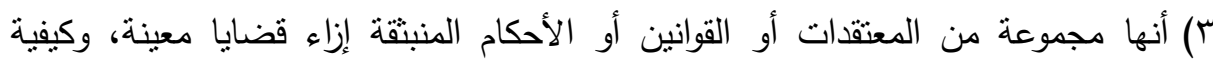
التصرف تجاهها، وهي نتاج اجتماعي، نم استيعابها من البيئة الثقافية لتقويم الممارسات الإنسانية تجاه قضايا البيئة.

وأهمية القيم البيئية تتمنل أيضا في كونها أساساً لاعم قيم إنسانية أخري، فقيمة صيانة

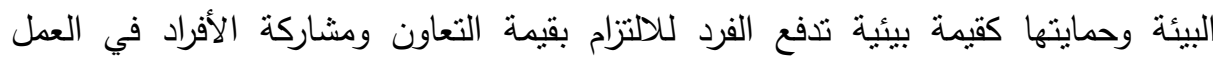
الجماعي والتي تعتبر قيمة إنسانية أشنمل. خصائص القيم البيئية: أن للقيم عدداً من الخصائص التي تميزها عن عن غيرها من المفاهيم

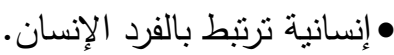
•تتأثر بمعلومات الفرد وخبراته واتجاهاته وتؤثر فيها. •نسبية؛ أي تختلف من شخص لآخر ، ومن مكان إلى مكان، ومن ثقافة إلى ثقافة.

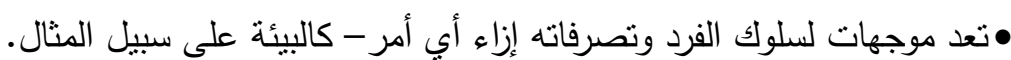
•تضضمن نوعا من الرأي أو الحكم على شخص أو شئ شئ أو معنى معين.

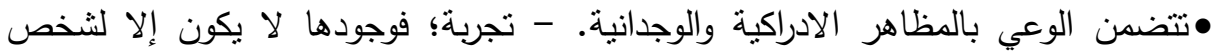

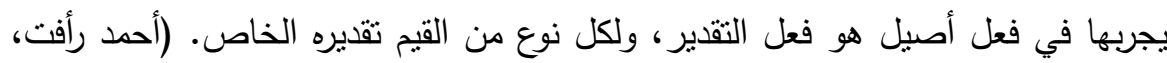

مستويات القيم البيئية: يقصد بمسنويات القيم البيئية: عند أي مستوى يمكن تعلمها وتتميتها لدى الطلاب، ويعد تصنيف كل من "كرثوول Krathwohl" و "بلوم Bloom" و "ماسلو

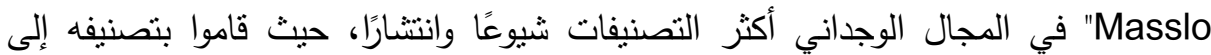


خمسة مستويات هرمية، يمكن تقسيمها إلى خمسة مستويات هرمية هي: الاسنقبال،

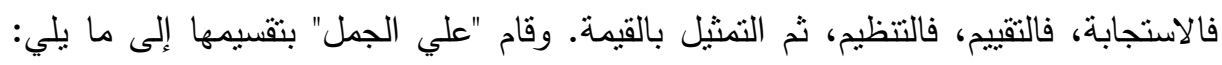
مستوى ما قبل تكوين القيمة، ثم مستوى ما بعد تكوين القيمة، حيث تعد القيمة أعلى مستويات هذا التصنيف. ثم بعد ذلك يأتي مستوى القيم وما بعد تكوينها، ولقد عبر عنها بالثكل التالي:

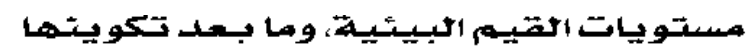

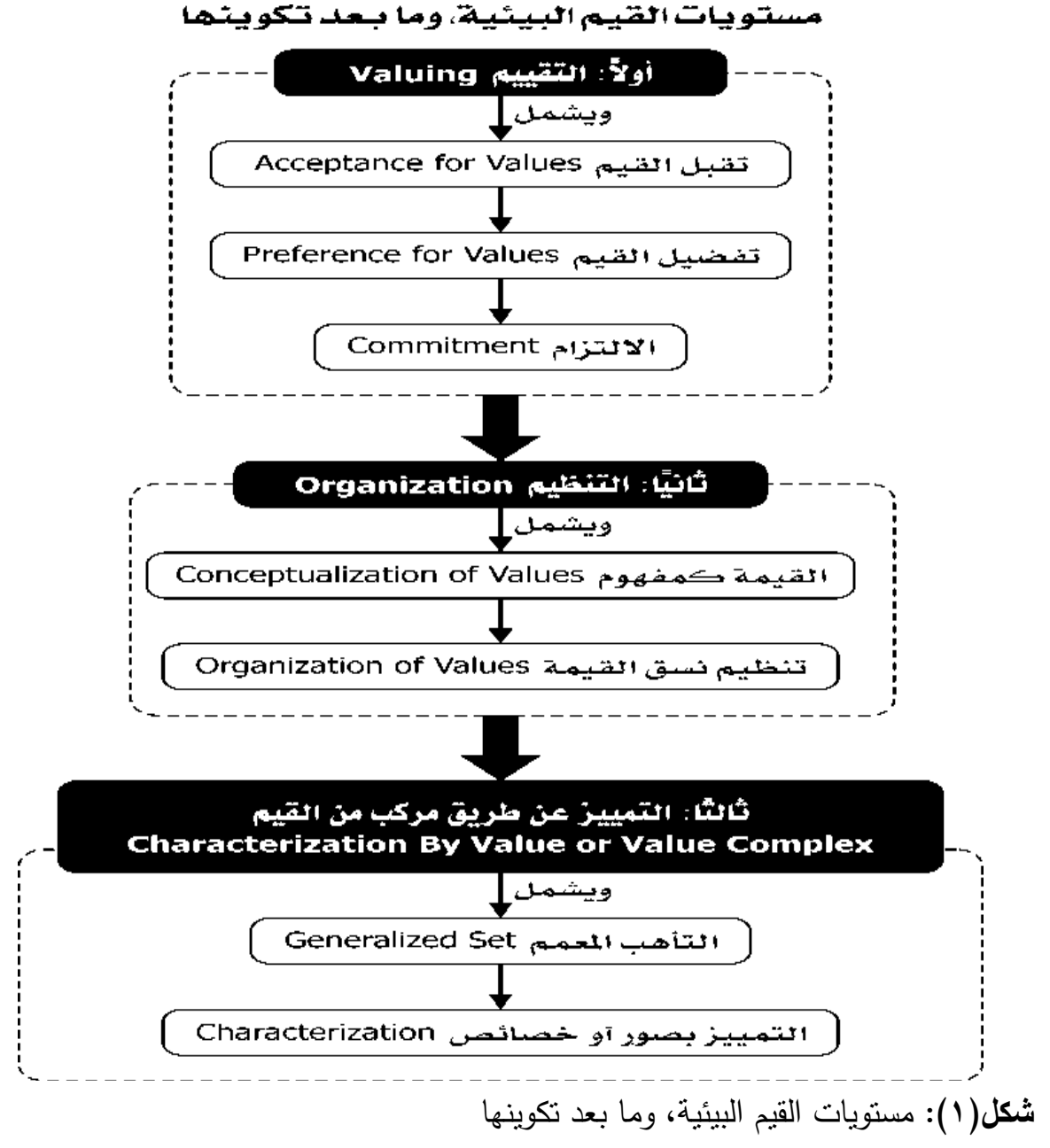

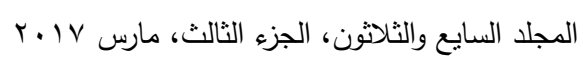


ويمكن نوضيح المفاهيم السابقة وما يندرج تحتها من مظاهر على النحو التالي: وميول،

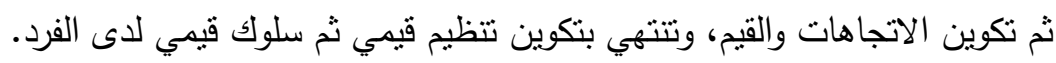

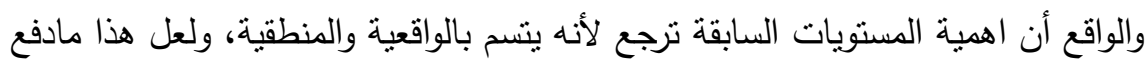
كثثر من الباحثين إلي تنبيه ،والواقع أنه يستتد في الاساس إلي تفسير (كراثول، باتهاته

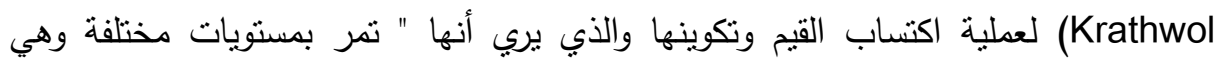
المعرفة (وتعد بداية للإدراك) يليها الوعي بموضوع القيمة( فبعد أن يعرف الفرد موضوعا معيناً

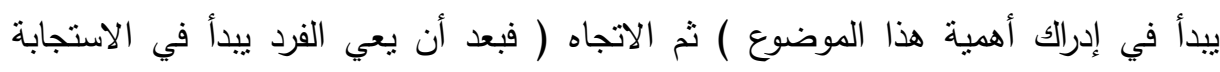
لموضوع القيمة إما بالقبول أو الرفض ومن ثم تتكون لدي الفرد مجموعة اتجاهات قد تكون

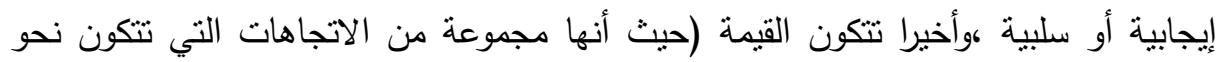

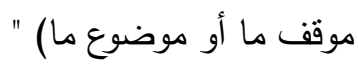

ثالثاً: المهارات البيئية: ان المهارات البيئية جزءا من المهارات الحياتية، وتتمنل المهارات

البيئية في:

•القيام بعمل محدد (عقلي أو بدني) يرنبط بالبيئة، في أقصر وقت وأقل جهد، مع تلافي

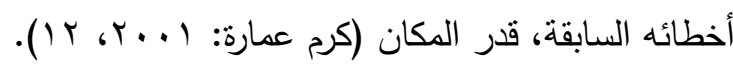

•مهارة من المهارات الحياتية (أي عمل يقوم به الانسان في الحياة اليومية التي يتفاعل فيها

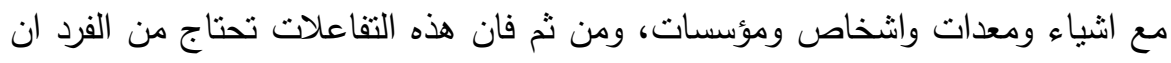

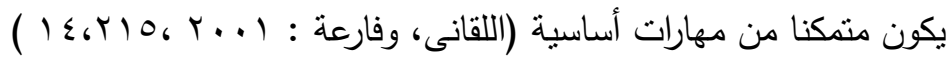

•مهارة من المهارات الحياتية" تناعد الأفراد على التفاعل مع مواقف الحياة اليومية، وتزودهم

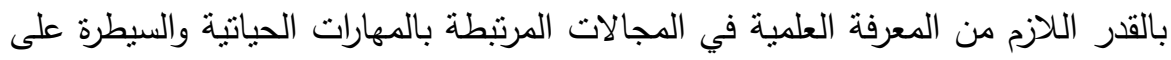
المشكلات الني تواجهرم في حباتهم ومجتمعهم وبيئتهم وتتشمل المهارات العلمية والتكنولوجية والمهارات البيئية، ومهارات الحفاظ على الحياة. (ثيماء صبحي 7 . . ب). 
وعرف الباحثون المهارات البيئية في هذا البحث بأنها " مجموعة من النشاطات البيئية

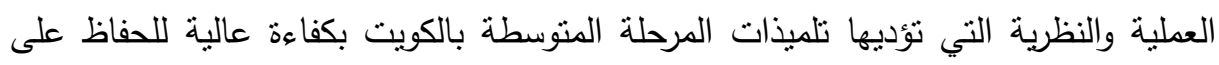

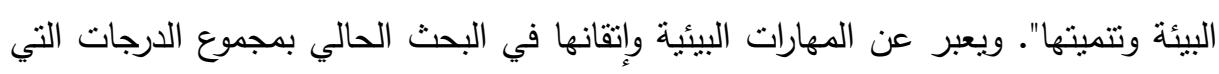
يحصل عليها تلميذات المرحلة المتوسطة على مقياس المهارات البيئية المعد لذلك. ويمكن التعرض لمراحل حل المشكلة البيئية من خلال المهارات التالية:

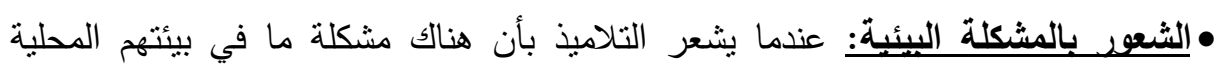

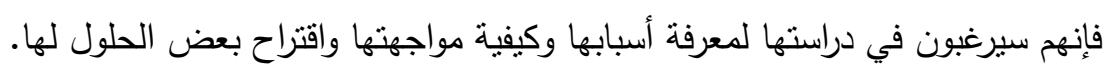

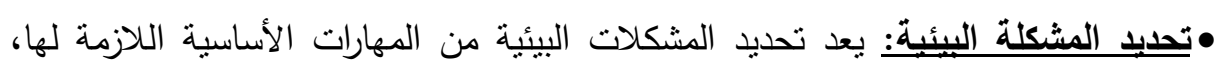
والخطوة الأولى لعملية فهمها. •جمع الييانات والمعلومات المتعلقة بالمشكلة البيئة: وينم ذلك عن طريق المسح الذي يجريه التلاميذ في بيئتهم المحلية لجمع المعلومات والمعلومات عن البيئة المحلية بواسطة طرق وأساليب متعددة مثل الملاحظة، المقابلة.

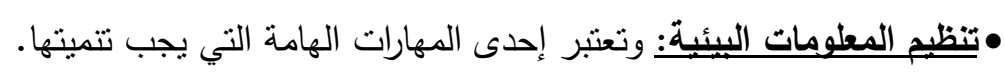

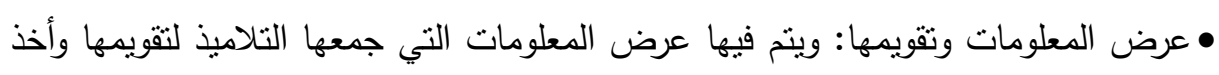
المعلومات الهامة المتعلقة بالمشكلة واستبعاد المعلومات التي لا تتعلق بالمشكلة.

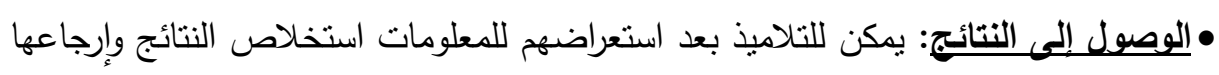
إلى أسبابها وتحديد الآثار التي يمكن أن تترتب على التى النتائج وتحليلها.

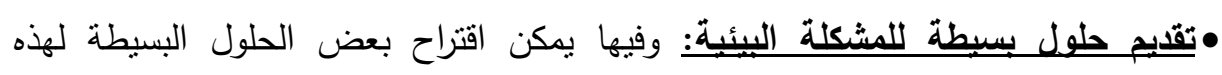

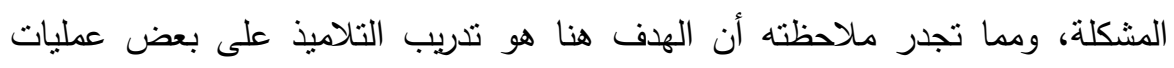

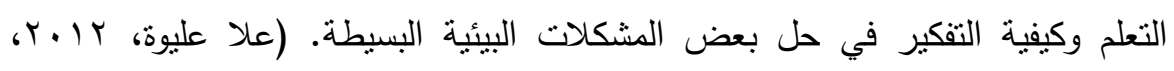

$$
\text { (07-00 }
$$

ويلاحظ أن هذه المهارات جميعها متضمنة في المهارات العامة فالاستماع مع الفهم إحدى مهارات الاكتساب، وإدراك المشكلة متضمنة في مهارات التتاول، وتحديد المشكلات

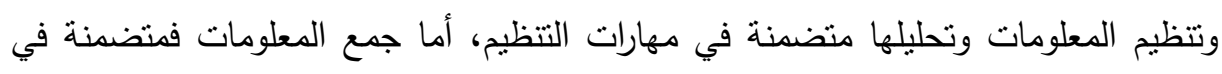


مهارات الاكتساب، اقتراح الحلول البديلة متضمنة في مهارة الابتكار، ووضع خطة العمل متضمنة في مهارات التتاول. دور الانشطة الصفية والللاصفية فى تنمية المهارات البيئية: ان الانشطة الصفية والللاصفية لها دور كبيرا في تنمية المهارات البيئية وذلك من خلاده اتاحة الفرصة لتلميذات المرحلة المتوسطة بدولة الكويت في: المئه

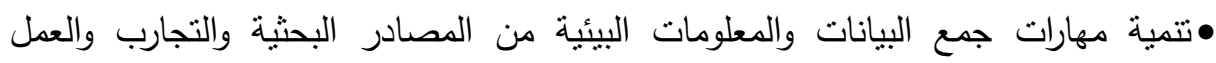
الميداني والرصد البيئي والملاحظة والتجريب والاستقصاء “من خلال رحلات أو زيارات إلى مواقع تشهد مشكلة بيئية معينة. •تتمية مهارات تتظيم البيانات وتصنيفها وتمثيلها وتحليلها واستعمال الوسائل المختلفة للبحث والاستقصاء والعرض. •تمية مهارات وضع خطط عمل مبسطة لحل المشكلات البيئية أو صيانة وتتمية الموارد

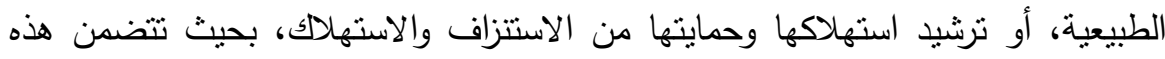

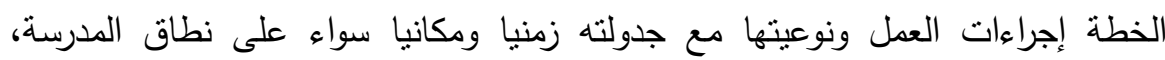
المنطقة المحيطة. •تتمية مهارة تتظيم دراسات في الرصد البيئي والتجارب البيئية وبناء مشاريع مبسطة يمكن تتفيذها في المدرسة بناء على نتائج هذا الرصد.

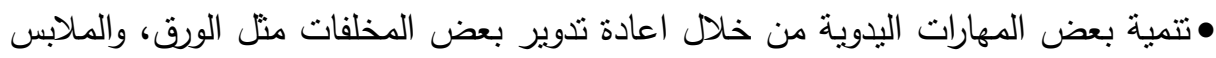
القديمة وغيرها من الاشياء اتى يتم التخلص منها بدون الاستفادة بها.

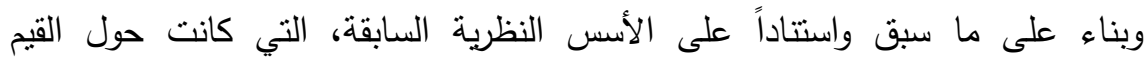
والمهارات البيئية والأنشطة ودورها في دعم وتتمية القيم والمهارات البيئية، فإن الباحثون

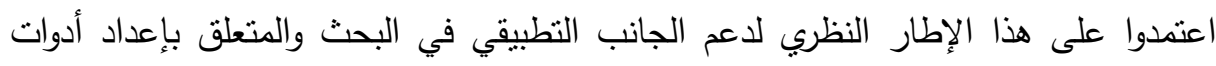
البحث وإعداد البرنامج وأدواته التي يمكن من خلالها التحقق من تتمية القيم والمهارات البيئية لتلميذات المرحلة المتوسطة بدولة الكويت. 


\section{إلجراءائ الهمبه}

للإجابة عن أسئلة البحث والتحقق من صحة الفروض نم اتخاذ الإجراءات التالية: للإجابة عن السؤال الأول والثاني للبحث:

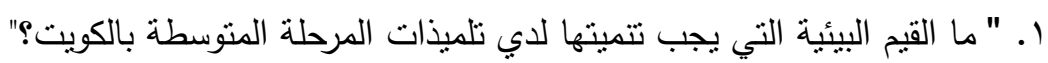

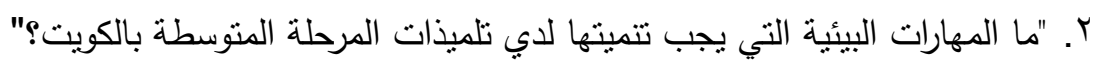

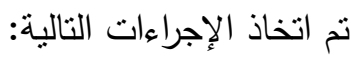
•مراجعة الأدبيات العربية والأجنبية الخاصة القيم والمهارات البيئية. •تحديد مفهوم القيم والمهارات البيئية. •تحديد القيم البيئية والمهارات البيئية التي بسعى البحث لدراستها والمناسبة لنلميذات المرحلة المتوسطة.

•وضع قائمة القيم والمهارات البيئية في صورتها الأولية. • عرض قائمة القيم والمهارات البيئية على مجموعة من المحكمين. •وضع قائمة القيم والمهارات البيئية في صورتها النهائية وقد تضمنت خمنه خمسة قيم رئيسة وثمانية وثلاثون مهارة فرعية، وهي: - تذوق جمال البيئة الطبيعية - المحافظة على بيئة الكويت نظيفة بدون تلوث النهاث - تقدير قيمة المحميات الطبيعية - الاستخدام الأمتل لموارد البيئة - المشاركة الإيجابية في تحسين البيئة • إعداد قائمة القيم والمهارات البيئية في صورتها النهائية: نم إعداد قائمة بالقيم والمهارات البيئية التي ينبغي تتميتها لاى تلميذات المرحلة المتوسطة، وتم: ا ـ مراجعة الدراسات والبحوث السابقة التي تتاولت القيم والمهارات البيئية. r. أراء الخبراء والمتخصصين في التربية والثأن البيئي. r. المراجع التي تتاولت مفهوم القيم البيئية والمهارات البيئية وخصائصها، وعناصرها وأنيات وأهميتها بالنسبة للمراحل التعليمية. 
تم وضع مبدئية للقائمة وبعدها تم تعديل القائمة المبدئية في ضوء أراء المحكمين وبذلك تم التوصل إلى قائمة تحتوي على خمسة(0) قيم بيئية رئيسية يندرج تحتها خمسة فئه وعشرون(Y0) مهارة بيئية فرعية.

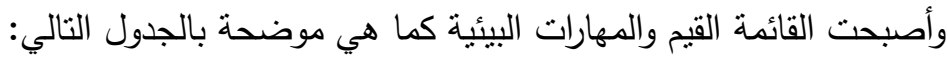
جدول( ا ): قائمة القيم والمهارات البيئية (صورة نهائية)

\begin{tabular}{|c|c|c|}
\hline المهارات البيئية & القيمة البيئية & م \\
\hline 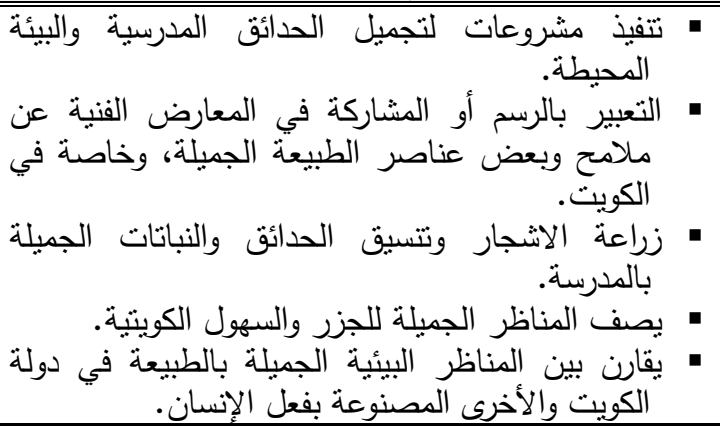 & 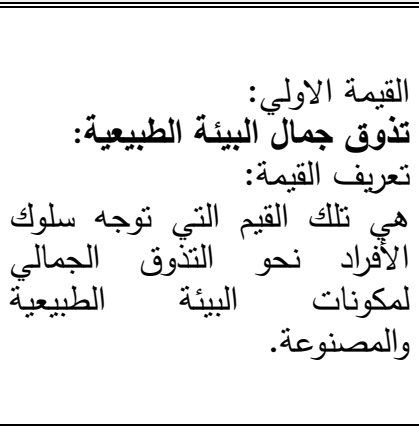 & 1 \\
\hline 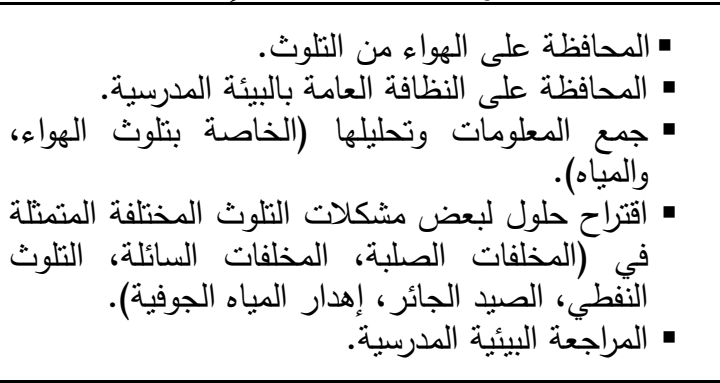 & 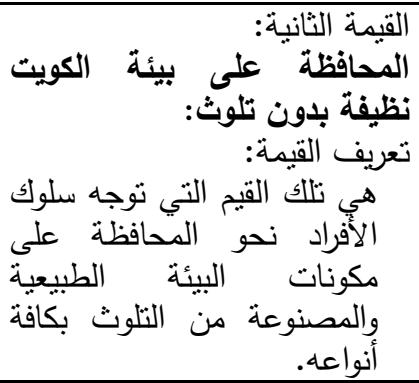 & r \\
\hline 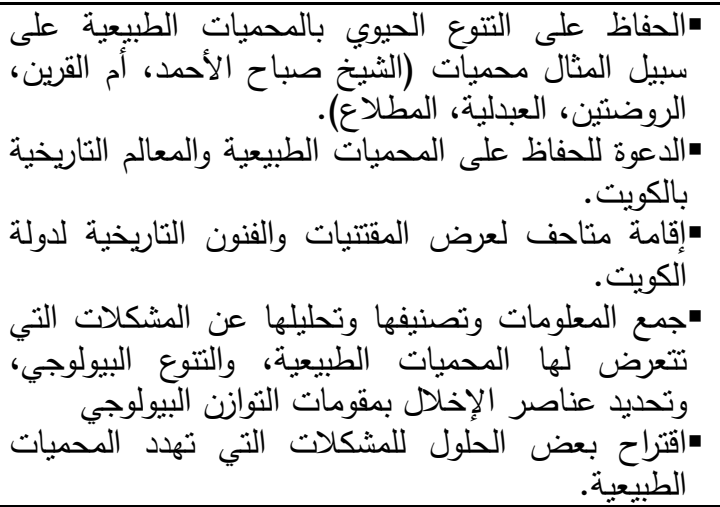 & تقديف أقيمة القيمة: المحميات الطبيعية: & r \\
\hline
\end{tabular}

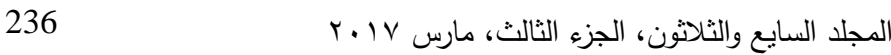


تابع جدول( (1): قائمة القيم والمهارات البيئية (صورة نهائية)

\begin{tabular}{|c|c|c|}
\hline المهارات البيئية & القيمة البيائية & م \\
\hline 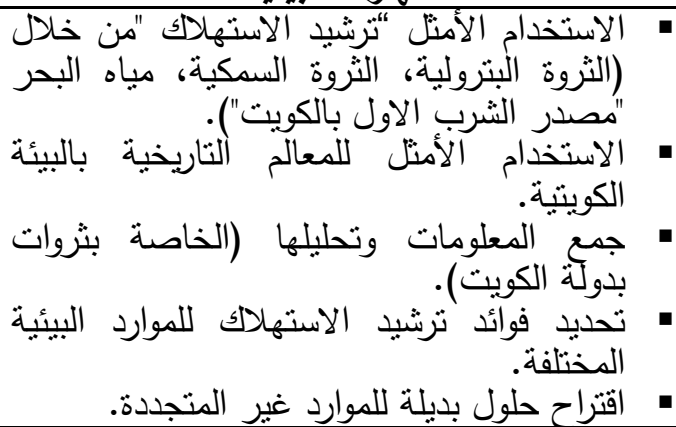 & 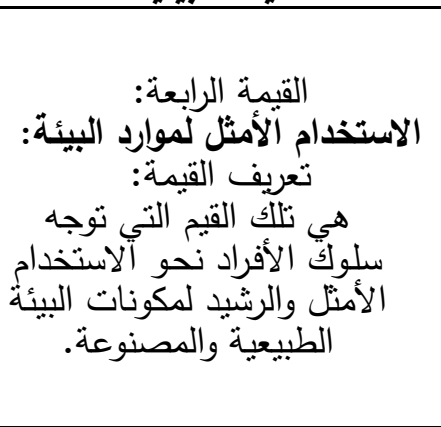 & $\varepsilon$ \\
\hline 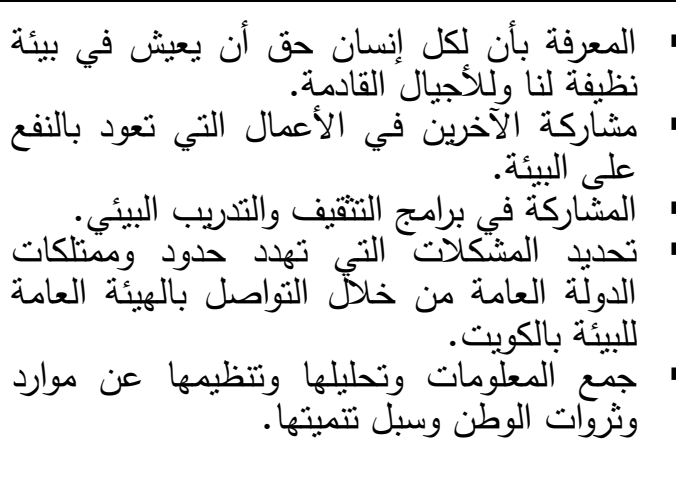 & 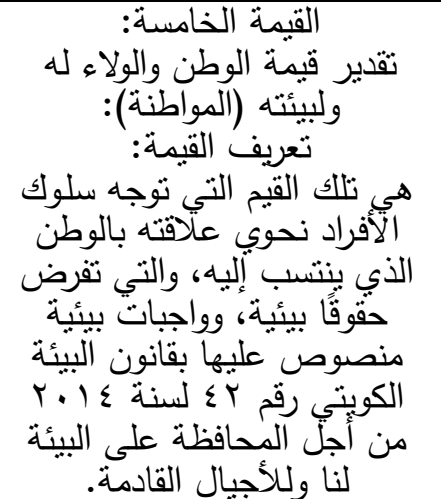 & 0 \\
\hline
\end{tabular}

ويذلك يكون البحث قد أجاب عن السؤلين الأول والثاني للبحث، وهما:

•ما القيم البيئية التي يجب نتميتها لدي تلميذات المرحلة المتوسطة بالكويت؟

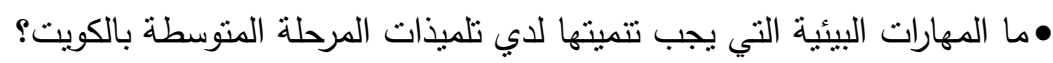

للإجابة عن السؤال الثالث للبحث"ما مدى توافر هذه القيم وإلمهارات البيئية في البرامج

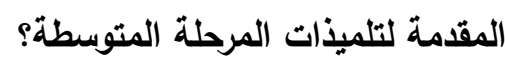

تم إعداد استطلاع الرأي للتعرف على مدى توافر القيم والمهارات البيئية لتلميذات المرحلة المتوسطة:

نم إعداد استمارة لاستطلاع الرأي حول مدي توافر هذه القيم والمهارات البيئية في البرامج المقدمة لتلميذات المرحلة المنوسطة من خلال الأنشطة في العملية التعليمية. 
وكان الهدف من استطلاع الرأي: هو استطلاع رأي المعلمين والمختصين القائمين على المرحلة المنوسطة بالكويت حول مدى تتاولهم للقيم والمهارات البيئية بالمناهج والبرامج رانج التعليمية من خلال ممارساتهم بالأنشطة المخططة في العام الدراسي، والتي تم إعدادها سابقاً.

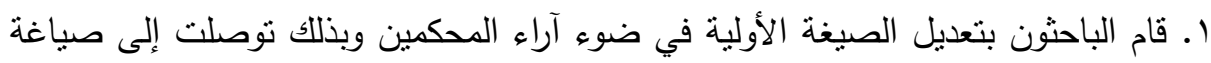
نهائية تحتوي على محورين رئيسيين يندرج تحتها خمسة وعشرون عبارة (Y0) استخبارية

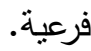

(أ)- إعداد استمارة استطلاع الرأي تتضمن العبارات التي تم الاستقرلا عليها، وتتكون من محورين رئيسين وهما:

• المحور الأول: يختص بتحديد مدي تتاول القيم والمهارات البيئية من خلال الإدارة التعليمية وخططتها التتفيذية، ويتكون من أحدى عشر عبارة مقترحة، أرقام (1-11) وذلك من من

$$
\text { خلال مقياس من قسمين (تتتاول - لا تنتاول). }
$$

• المحور الثاني: يختص بتحديد مدي تتاول المعلمين والمختصين للأنشطة اللاصفية للقيم

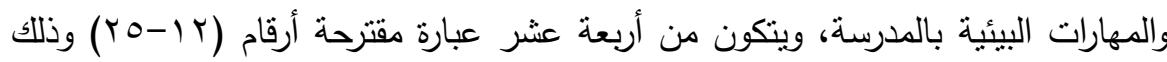

$$
\text { من خلال مقياس من قسمين (تتناول - لا تتتاول). }
$$

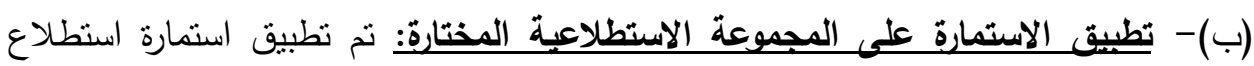

$$
\text { الرأي على السادة المحكمين على أدوات البحث. }
$$

(ج)- استخلاص النتائج وتحليلها ومناقشتها: تم جمع الاستمارات المقدمة للمجموعة المختارة

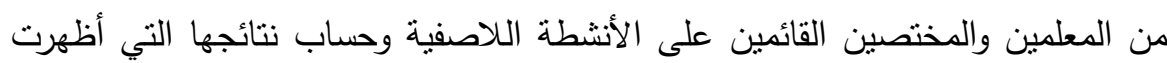

\begin{tabular}{|c|c|c|c|}
\hline اللمبة المئوية & متوسط درجة الافراد & المحورة - ل المور & المحور \\
\hline$\varepsilon Y, Y V$ & $\varepsilon, 70$ & 11 & 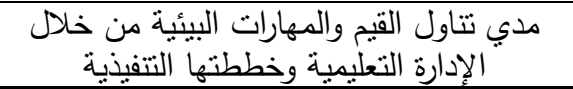 \\
\hline ס סז,זי & $\Lambda, \wedge \vee$ & $1 \varepsilon$ & 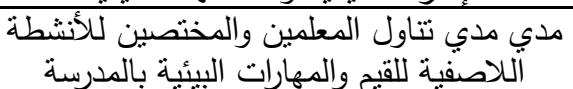 \\
\hline $0 \varepsilon_{,}, 1$ & IT,OY & ro & المجموع الكلى \\
\hline
\end{tabular}

جدول رقم(ץ): المجموع الكلي للنسبة المئوية لمتوسط المحورين

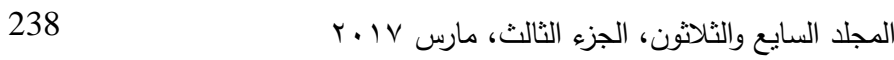


يوضح جدول رقم (Y) أن النسبة المئوية للمتوسط للمحور الأول الذي يختص بتتاول

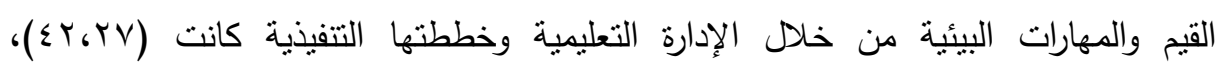

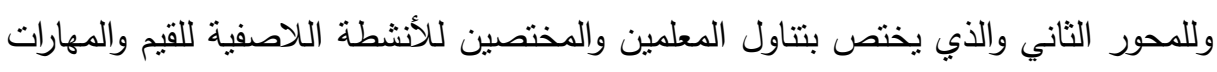

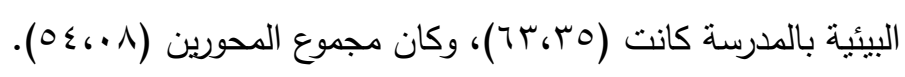

مما بعني انه لم تكن الأنثطة اللاصفية بالمرطلة المتوسطة تنتاول القيم والمهارات

$$
\begin{aligned}
& \text { البيئية بالقدر الكافي الذي ينمي هذه القيم والدهارات البيئية لديهن. } \\
& \text { ويذلك قد تمت الإجابة على السؤال الفرعي الثالث للبحث وهو : }
\end{aligned}
$$

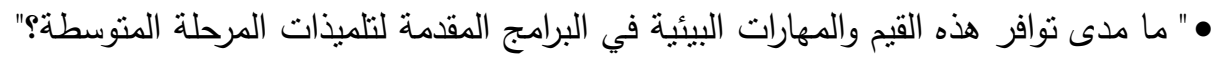

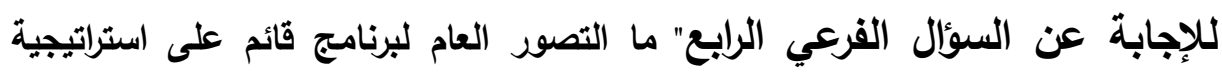

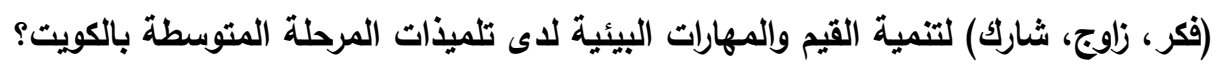

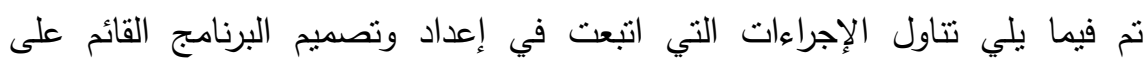

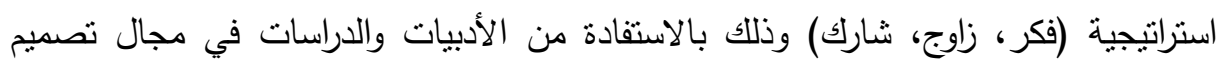

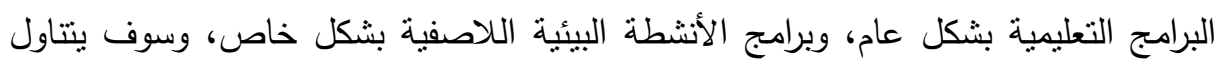

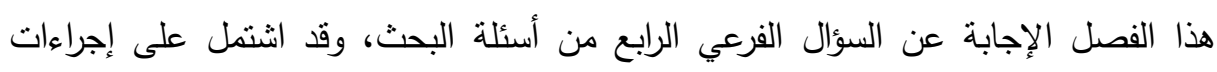

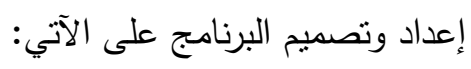

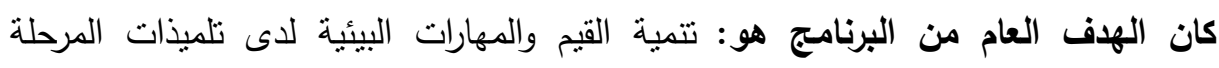
المتوسطة باستخدام استراتيجية (فكر ، زاوج، شارك). الأهداف الخاصة للبرنامج: من المتوقع في نهاية البرنامج أن تكون التلميذة قادرة علكر

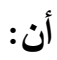
•تعرف مفهوم القيم البيئية.

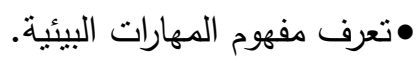
•تندرك المهارات المختلفة للتعامل مع البيئة. •تميز بين الحق في البيئة النظيفة والالتزام بالحفاظ عليها نظيفة لنا ولغيرنا. •تعرف أهمية العوارد البيئية وكيفية حمايتها واستثمارها. •تفهم خطط وجهود دولة الكويت في المحافظة على البيئة وتتميتها.

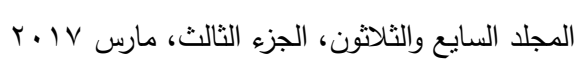


•تاقش بعض المبادئ الواردة في قانون البيئة الكويتي والمواثيق الدولية المرتبطة بالقيم والمهارات التعامل مع البيئة.

•تحدد بعض المهارات البيئية الملحة لمواجهة مشكلات البيئة الكوينية. •تعي الأخطار التي يمكن أن تلحق بالدولة جراء سلوكيات الأفراد السلبية تجاه البيئة. •تدرك أهمية التعاون والتفكير الإيجابي لمعالجة القضايا البيئية المحلية والعالمية. •تقيم موقف الدولة ايجاباً وسالباً من تطبيق القيم البيئية في التعامل مع البيئة. •توضح دور الفرد للمساهمة في اتخاذ القرارات لصالح البيئة. •تفهم الترابط بين البيئة والانسان والعلاقات المنبادلة بينهم. •تجمع مقالات متتوعة عن القيم والمهارات البيئية المختلفة للتعايش مع البيئة. •تشارك بفاعلية للقيام بأعمال داخل المدرسة وخارجها لحل المشكلات البيئية. •تقدر قيمة المحميات الطبيعية وضرورة الحفاظ عليها. •تحترم الحقوق البيئية للآخرين.

•تحلل المشاكل البيئية التي تتعرض لهابه البيئة الكويتية. •تساهم في اتخاذ القرارات المناسبة للحد من التعدي على البيئة والإساءة لها. •تكتسب مهارات التعلم التعاونية لصالح البيئة.

محتوى البرنامج المقترح: تم تخطيط البرنامج وتصميمه بعد التعديل الذي اقترحه المحكمون

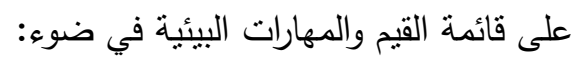
ا ـ الأهداف السابق عرضها. r. مراعاة تحديد أهداف النشاط ومؤشرات الأداء والمحتوى واستراتيجية التدريس بدقة ووضوح وأن تكون قابلة للقياس. r. مراعاة تضمين مكونات البرنامج مواضيع متتوعة تغطي أنشطة لاصفية بيئية بصورة

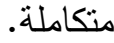

ع. مراعاة قابلية البرنامج للنطبيق في البيئة الكوينية. 
ه. مراعاة شمول البرنامج أنشطة بيئية لاصفية قادرة على إكساب التلميذات قيم ومهارات بيئية مرتبطة بحياتهم اليومية وبيئتهم المحيطة.

وتكون محتوى البرنامج المقترح من عشرون(· •r) نشاطاً لا صفي وقد تم تنظيم أنشطة

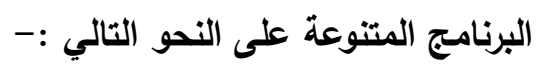
أهـاف النشـاط :- نم صياغتها إجرائياً حتى يمكن التأكد منها أثناء النشاط. خطوات إجراء النشاط وفق استراتيجية (فكر - زاوج - شارك):- ويعتمد استخدام استراتيجية "فكر ، زاوج، شارك" لتحقيق هدف كل نشاط وفقا لمراحل الاستراتيجية كما يلي:ا ـ اولاً : التمهرجيد

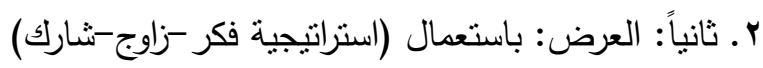

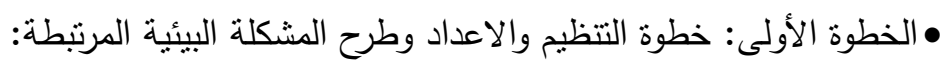
• الخطوة الثانية: خطوة التفكير الفردي • الخطوة الثالثة: خطوة المزاوجة

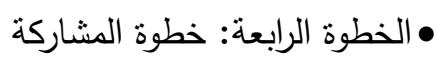
r. ثالثاً: التطبيق ع. رابعاً: الثقويم

ضبط البرنامج والتأكد من صلاحيته: بعد الانتهاء من إعداد البرنامج، نم ضبطه عن طريق عرضه على مجموعة من المحكمين للتعرف على آرائهم من حيث:

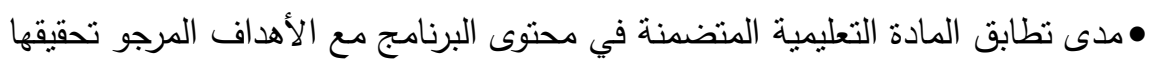

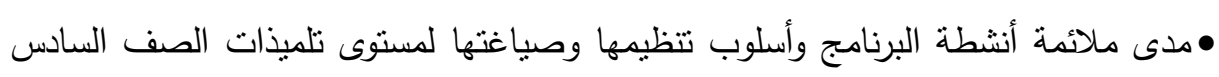
بالمرحلة المتوسطة بالتعليم الإلزامي بالكويت.

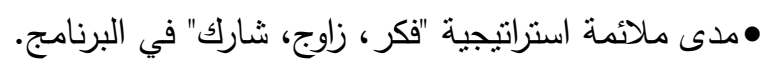

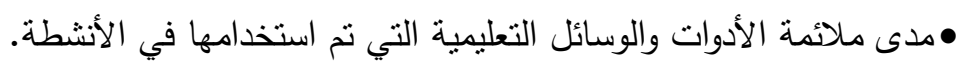

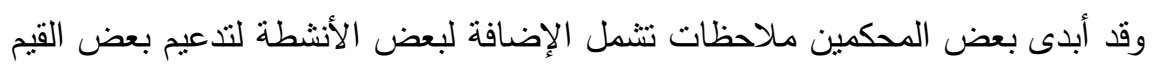
والمهارات البيئية أو تعديلا في بعض الأنشطة أو حذفاً لبعض الأنشطة التي لا حاجة لها وقد الإند

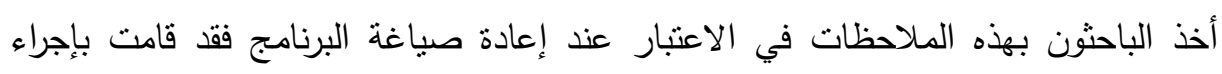

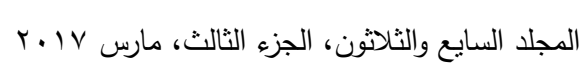


التعديلات اللازمة في البرنامج في ضوء هذه الملاحظات حتى أصبح البرنامج بصورته النهائية جاهزاً للتطبيق. ويذلك قد تمت الإجابة على السؤال الفرعي الرابع من أسئلة البحث وهو :

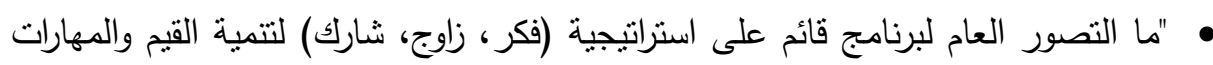

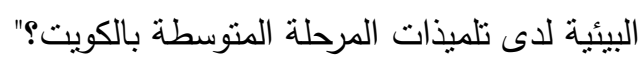
للإجابة على السؤال الخامس: ما فاعلية البرنامج المقترح في تنمية القيم والمهارات البيئية لاى تلميذات المرحلة المتوسطة بالكويت؟ وللتعرف على فاعلية البرنامج المقترح في تتمية القيم والمهارات البيئية، كان لابد من بن لانديات

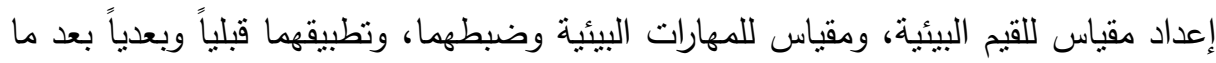
تم التعرض للبرنامج المقترح المتضمن للأنشطة البيئية وادائها من قبل التلميذات ونطيات بالمرحلة

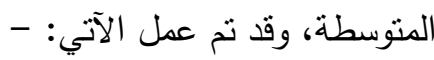
أولاً : إعداد مقياس القيم البيئية أسئلة المقياس تم صياغتها على شكل مواقف بيئية تعبر عن رأى التلميذة في البيئة المحيطة بها، وتوجد أسفل هذه العبارة أربعة اختبارات توضئ فئح تسلسل الاستجابة للقيم حتى تصبح قيمة مناسبة للموقف البيئي الموضح.

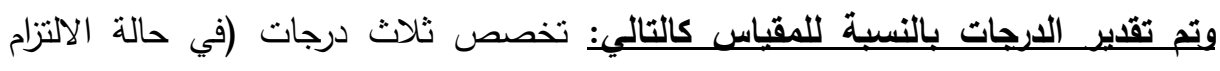
بالقيمة)، ودرجتين (في حالة تفضيل القيمة)، ودرجة واحدة (في حالة قبول القيمة)، ولا شيء للقيمة السلبية، وبذللك يكون المجموع الكلى لدرجات المقياس خمس وسبعون درجة ونه (V0). وتم حساب الصدق الظاهري: ويتعلق بالثكل العام للمقياس، وللتحقق من الصدق تم عرض لترن المقياس في صورته المبدئية على مجموعة المحكمين الذين شاركوا في تحكيم البرنامج وأدوات

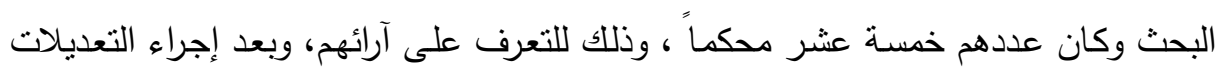

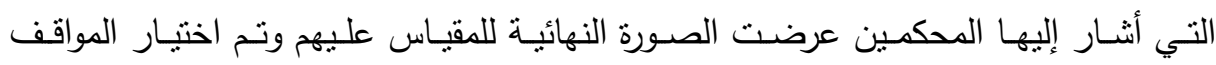

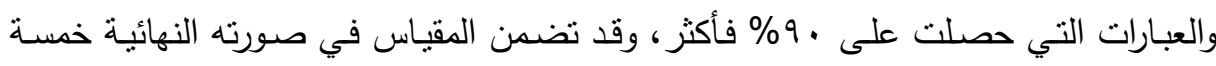
وعثرين(Y0) عبارة وموقف موزعة على القيم البيئية الخمسة. 
ثبات المقياس: وقد استخدم الباحثون الطريقتن التاليتين للحصول على معامل ثبات المقياس:

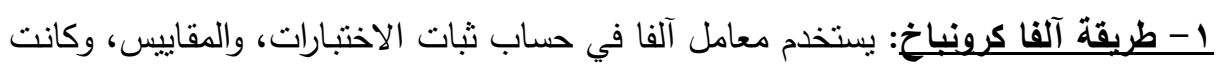

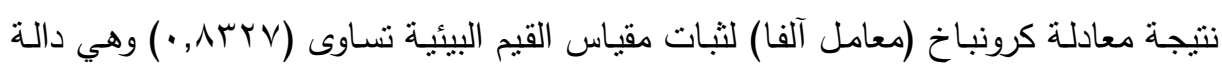

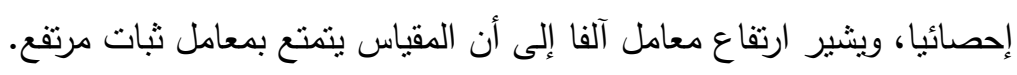

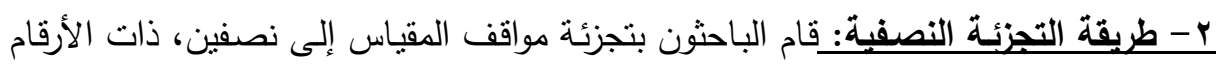

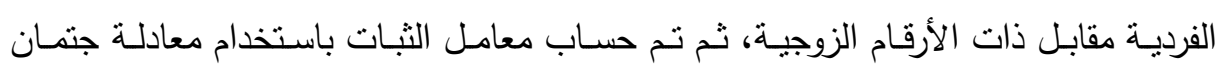

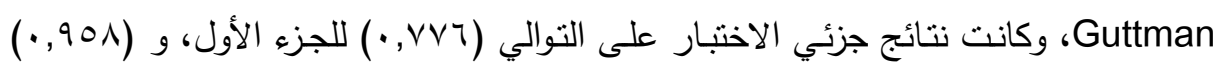

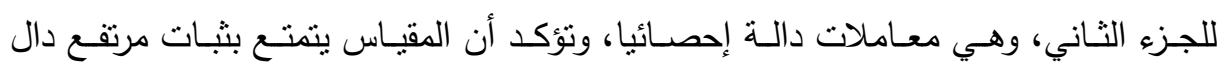
إحصائيا.

وبذلك أصبح المقياس في صورته النهائية ومعداً لقياس القيم البيئية (الملحق رقم ؟).

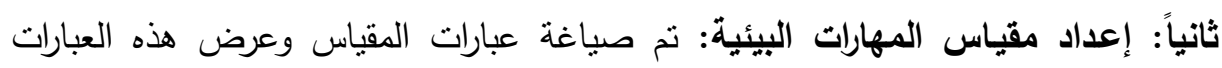

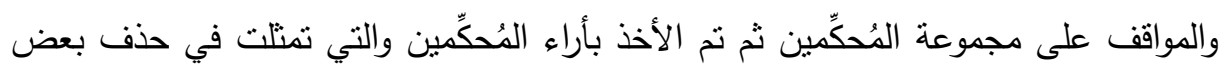

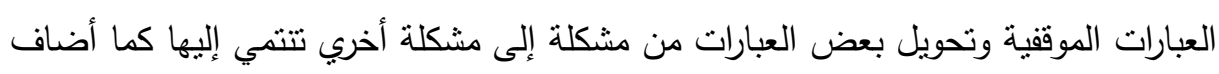

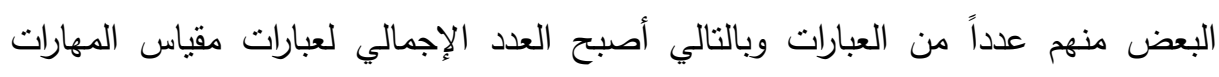
البيئية كما يلي: • مقياس المهارات البيئية (؟س) عبارة موققية موزعة على محاور المقياس كما هو موضح بالجدول رقم (ץ)، (ع) ومحاور المقياس والدرجة الكلية لكل محور ومفردة.

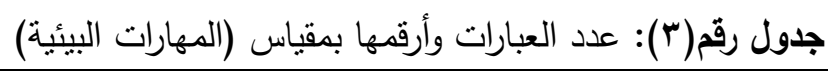

\begin{tabular}{|c|c|c|}
\hline أرقام المفردات & العبارات & المهارة البيئية \\
\hline $1 \cdot-9-\lambda-V-\nearrow-0-\varepsilon-r-Y-1$ & 1. & • إدارك المشكلات البيئية وتحديدها \\
\hline $\begin{array}{c}-1 V-17-10-1\{-1 Y-1 Y-11 \\
r \cdot-19-11\end{array}$ & 1. & • نتظيم البيانات البيئية وتحليلها \\
\hline$-Y V-Y\urcorner-Y 0-Y \xi-Y Y-Y Y-Y I$ & 1. & • إقتراح الحلول للمشكلات البيئية \\
\hline \multicolumn{2}{|l|}{ r. } & المــجموع \\
\hline
\end{tabular}


جدول(§): الأقسام التي يتكون منها مقياس المهارات البيئية والدرجة الكلية لكل منها، وهو

\begin{tabular}{|c|c|c|c|}
\hline & & \multicolumn{2}{|c|}{ 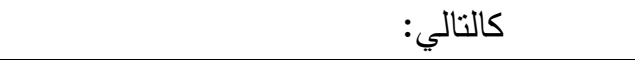 } \\
\hline الادجة الكلية & عداد المفردات & المهارة التى يقيسها & الاختبار \\
\hline 1. & 1. & إدراك المشكلات البيئية وتحديدها & 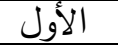 \\
\hline r. & 1. & تتظيج والبيانات البيئية وتحليلها & 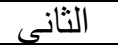 \\
\hline r. & 1. & اقتراح الحلول للمشكلات البيئية & 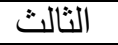 \\
\hline •0.(درجة) & • ب(مفردة) & \multicolumn{2}{|l|}{ 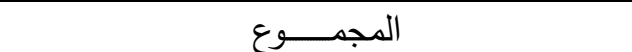 } \\
\hline
\end{tabular}

التجرية الاستطلاعية: بعد الانتهاء من الخطوات السابقة تُعيّن على الباحثون تطبيق الصورة

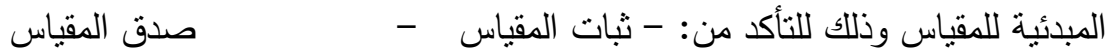
ولتحقيق ذلك قام الباحثون بتطبيق الصورة المبدئية لمقياس المهارات البيئية على مجموعة استطلاعبة تلميذات (مدرسة عاتكة بنت عبد المطلب بن هاشم المتوسطة للبنات) لمجموعة اخري غير المجموعة التجريبية قوامها • ب تلميذة وذلك بهذف حساب ثنات وصدق

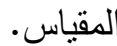
صدق المقياس وثباته: قام الباحثون بعرض المقياس على المحكمين من أهل الاختصاص ونم الأخذ بآراء المُحكِّمين في مجال التربية البيئية وخبراء بالإدارة التعليمية لاستطلاع آرائهم بشأن مدى مناسبة المقياس لتلميذات المرحلة المتوسطة من حيث صياغة العبارات الموقفية ومدى تمنثل هذه العبارات لمحاور المقياس وقد نم مراعاة التوصبات التي أجمع عليها

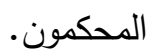

ثم نم التأكد من ثبات المقياس بإتباع طريقة التجزئة النصفية وقد طُبِّق مقياس المهارات البيئية على مجموعة من (• r) تلميذة من أحدى المدارس بالمرحلة المتوسطة.

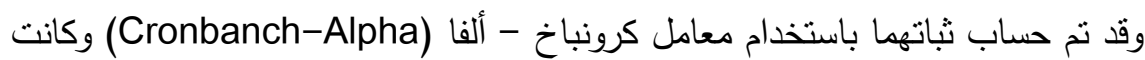

$$
\text { النتيجة (VTY, VT • ) لمقياس المهارات البيئية. }
$$

تنفيذ تجرية البحث وتشمل: نم اختبار مجموعة الدراسة من تلميذات الصف السادس بالمرحلة المتوسطة بالكويت، وقد بلغ عددها ·9 تلميذة من مدرسة اليسرة المنوسطة بنات، ـ تلميذة

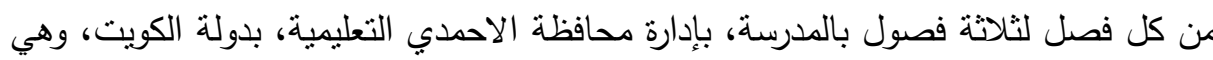


• عدد(•r) تلميذة من فصل سادس / أول.، وعدد(·r) تلميذة من فصل سادس / ثاني.

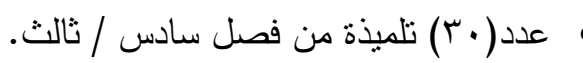

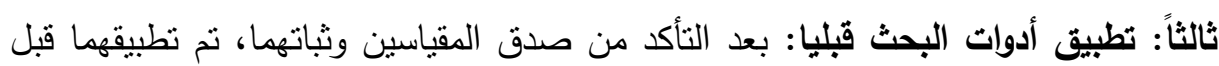
دراسة البرنامج على مجموعة الدراسة. ثم تم القيام بإجراءات التطيق المبداني التالية: -

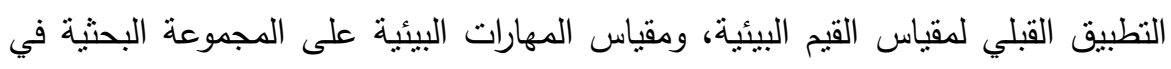

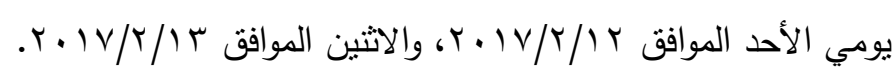

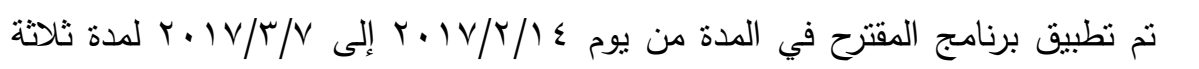

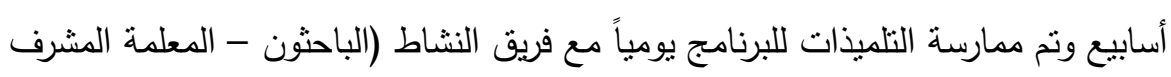
المعاونة في تطبيق الأنشطة - مشرفة الصف) أثناء اليوم الدراسي للمدة الزمنية لإنية المخصصة لكل نشاط.

تطيق البرنامجج المقترح: بعد أن تم عرض البرنامج على المحكمين بغرض الاستئناس بآرائهم

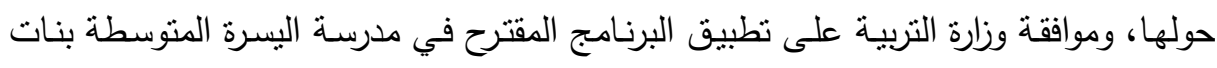

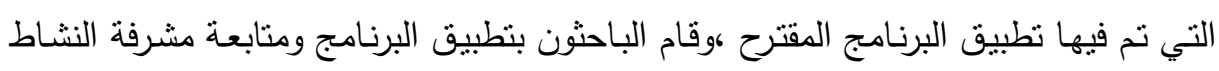

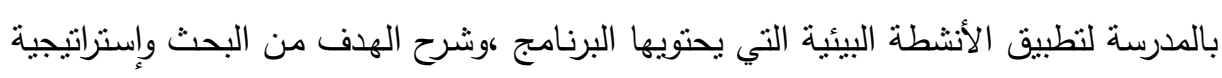

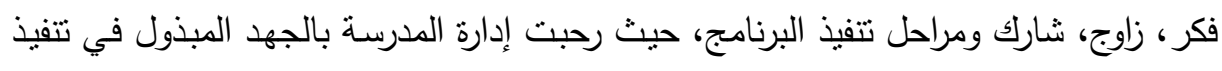

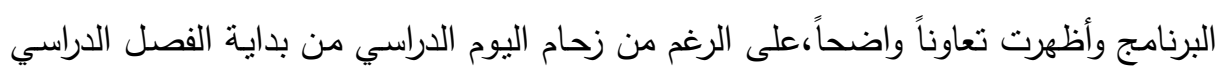

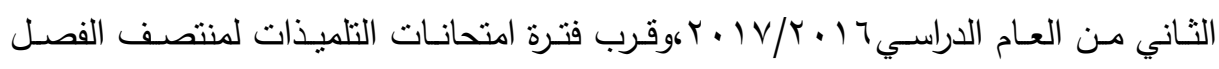
الدراسي الأول وفتزة استعداد الإدارة المدرسية لها.

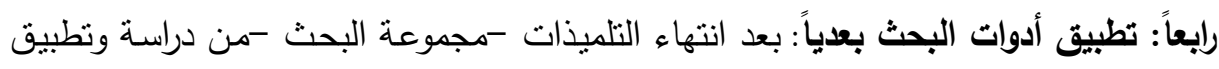
البرنامج المقترح، تم تطبيق مقياسي القيم والمهارات البيئية، كالتالي.

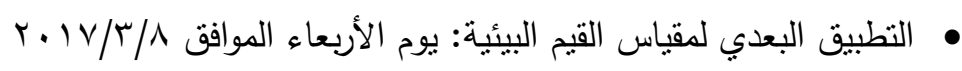

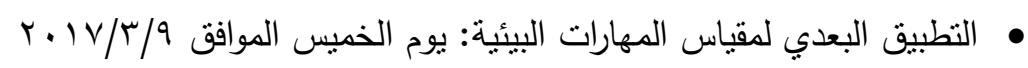




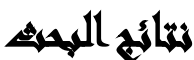

للتحقق من صحة الفرض الأول للبحث والذي ينص على: "توجد فروق دالة إحصائيًا بين

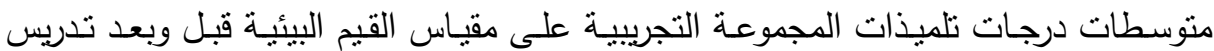
البرنامج المقترح لصالح التطبيق البعدي". وللتحقق من صحة هذا الفرض تم استخدام اختبار " ت " لقياس الفروق بين المتوسطات كما هو موضح في الجدول التالي:

جدول(ه): الفروق بين القياس القبلي والبعدي للمجموعة التجريبية في مقياس القيم البيئية

\begin{tabular}{|c|c|c|c|c|c|c|c|c|}
\hline الدستوية & الأثخ & ايتيا & الدرجية & قيمة"ت" & المعياري & المتوسط & "العد" & المجموعة البيان \\
\hline \multirow{2}{*}{$\cdot, .0$} & \multirow{2}{*}{ 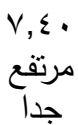 } & \multirow{2}{*}{ مرتفع ج جدا } & \multirow{2}{*}{19} & \multirow{2}{*}{$* * \curlyvee q, \cdot \vee \wedge$} & $r, 10$ & $r r, \leqslant 0$ & \multirow{2}{*}{9.} & قبلي \\
\hline & & & & & $1, r \mu$ & 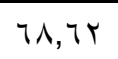 & & بعدي \\
\hline
\end{tabular}

يتضح من الجدول السابق رقم (•) ما يلي:

• منوسط درجات تلميذات المجموعة التجريبية في مقياس القيم البيئية، في التطبيق البعدي، أكبر من متوسط درجاتهم في التطبيق القبلي، حيث إن منوسط درجات التطبيق البعدي بلغ

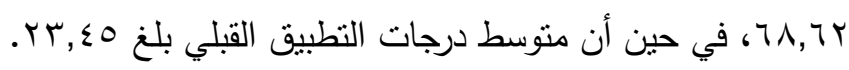

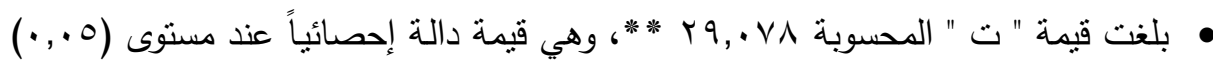

$$
\text { لصالح التطبيق البعدي. }
$$

وهذا يثير بدوره إلى وجود فروق ذات دلالة إحصائية عند مستوى (0. . •) بين متوسط

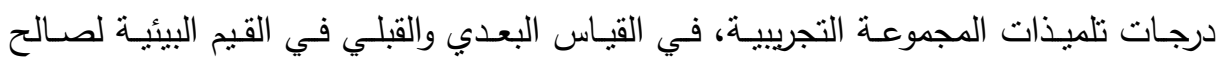
التطبيق البعدي، مما يثبت صحة الفرض الأول للبحث.

كذللك يتضح ان حجم تأثثر المتغير المستقل (برنامج قائم على استراتيجية فكر، زاوج،

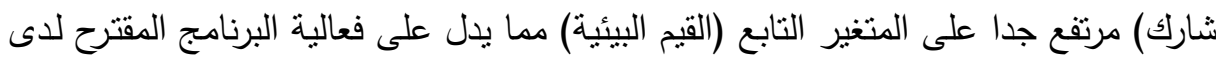
تلميذات المرحلة المنوسطة بالكويت. 
يمكن إرجاع تفوق درجات التلميذات في التطبيق البعدي إلى استخدام استراتيجية فكر

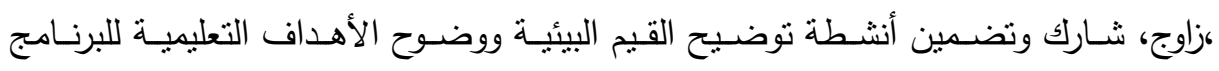

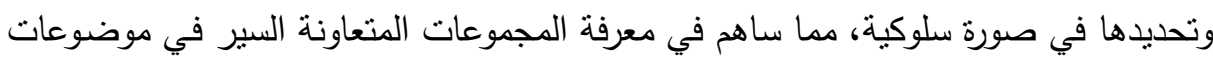

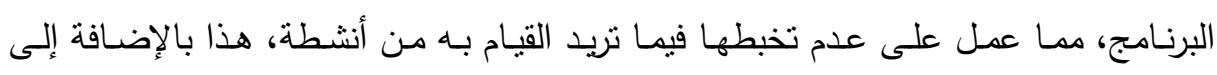

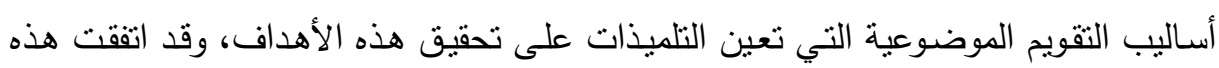

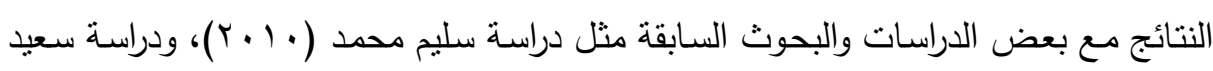

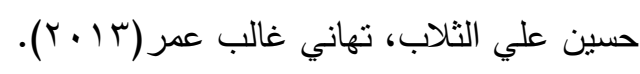
ثالثاً-النتائج المتعلقة بمقياس المهارات البيئية: للتحقق من صحة الفرض الثاني للبحث والأي ينص على: "توجد فروق دالة إحصائيًا بين متوسطات درجات تلميذات المجموعة التجريبية على مقياس

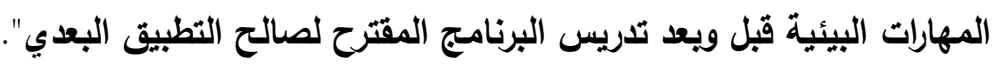
وللتحقق من صحة هذا الفرض نم استخدام اختبار " ت " لقياس الفروق بين المتوسطات لئل كما هو موضح في الجدول التالي: جدول(؟): قيم (ت) لدلالة الفروق بين منوسطي النطبيق القبلي والبعدي للمجموعة التجريبية

\begin{tabular}{|c|c|c|c|c|c|c|c|c|}
\hline الأثرّ & مريتًا & ت & لدرجات & المعياري & المتوسط & للالكألَّة & القياس & المهارة \\
\hline \multirow{2}{*}{ جرتفع 9,9 } & \multirow{2}{*}{ مرتفع } & \multirow{2}{*}{ 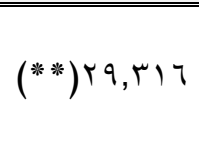 } & \multirow{2}{*}{19} & $1, \cdot r r$ & $V, V \varepsilon$ & \multirow{2}{*}{1.} & بعدي & \multirow{2}{*}{ الأشتركلة } \\
\hline & & & & $\cdot, 0 \vee \wedge$ & $r, \wedge V$ & & قبلي & \\
\hline \multirow{2}{*}{ جرتفع } & \multirow{2}{*}{ 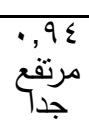 } & \multirow{2}{*}{$* * r q, 0 \ldots$} & \multirow{2}{*}{19} & 1,101 & 18,17 & \multirow{2}{*}{$r}$. & بعدي & \multirow{2}{*}{ والبيانات } \\
\hline & & & &., $07 \mathrm{~V}$ & $\wedge, 90$ & & قبلي & \\
\hline \multirow{2}{*}{ مرتجغ } & \multirow{2}{*}{ مرتفع } & \multirow{2}{*}{$* * 19, r$ r $q$} & \multirow{2}{*}{19} & I,rYq & $1 \Lambda, Y 7$ & \multirow{2}{*}{$r$. } & بعدي & \multirow{2}{*}{ اللمشكلات البئرل } \\
\hline & & & & $1, r 00$ & $1 \cdot, \times q$ & & قبلي & \\
\hline \multirow{2}{*}{ 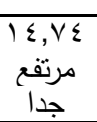 } & \multirow{2}{*}{ 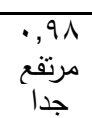 } & \multirow[b]{2}{*}{$* * \varepsilon \leqslant, \wedge \leq 0$} & \multirow[b]{2}{*}{19} & 1,911 & $\varepsilon r, 1\}$ & \multirow[b]{2}{*}{0 . } & بعدي & \multirow{2}{*}{ اللارجية } \\
\hline & & & & $1, r \leqslant r$ & $r Y, T)$ & & قبلي & \\
\hline
\end{tabular}

(") 


\section{يتضح من الجدول السابق رقم (؟) ما يلي:}

1- منوسط درجات التلميذات المجموعة التجريبية في مقياس المهارات البيئية، في التطبيق

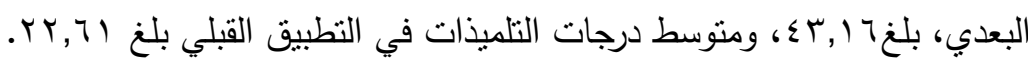

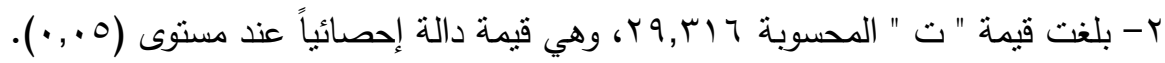

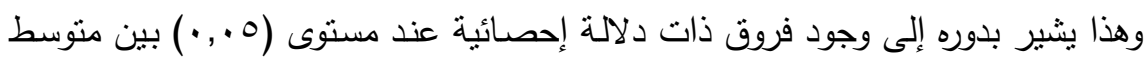

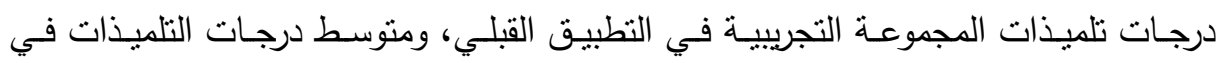
النطبيق البعدي لمقياس المهارات البيئية في كل من مكونات المهارات البيئية (إدراك المشكلة البيئية وتحديدها، نتظيم البيانات وتحليلها، واقتراح الحلول للمشكلات البيئية) والدرجة الكلية لصـالح التطبيق البعدي، مما يشبر الى تحقيق الفرض وفعالية البرنـامج. مما يثبت صحة الفرض الثاني للبحث.

كذلك يتضح أن حجم تأثثر المتغير المستقل (برنامج قائم على استراتيجية (فكر - زاوج

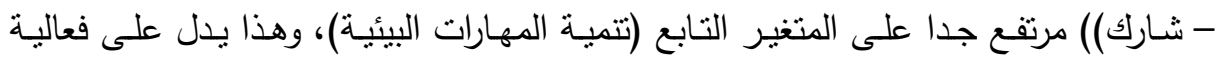
البرنامج المقترح لدى تلميذات المرحلة المتوسطة بدولة الكويت. رابعاً: النتائج المتعلقة ببطاقة ملاحظة الأداء: للتحقق من صحة الفرض الثالث للبحث والذي ينص على: "توجد فروق دالـة إحصائًًا بين متوسطات درجات تلميذات المجموعة التجريبية على بطاقة ملاحظة الأداء قبل

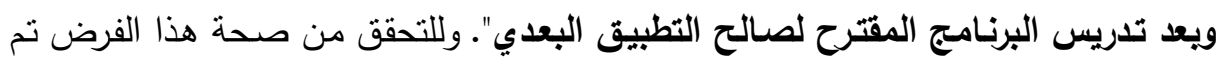
استخدام اختبار"ت" لقياس الفروق بين المتوسطات كما هو موضح في الجدول التالي: 
جدول(V): قيم (ت) لدلالة الفروق بين منوسطي النطبيق القبلي والبعدي للمجموعة التجريبية

\begin{tabular}{|c|c|c|c|c|c|c|c|c|}
\hline & & & & \multicolumn{5}{|c|}{ في بطاقة ملاحظة الأداء } \\
\hline الدلالة & $ت$ & الدرجاتة & الانحراف & المتوسط & الارجية & القياس & بطاقة الملاحظة & 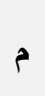 \\
\hline \multirow{2}{*}{$\cdot, .0$} & \multirow{2}{*}{17,17} & \multirow{2}{*}{19} & $\cdot, \Gamma \varepsilon$ & $\varepsilon, Y Y$ & \multirow{2}{*}{0} & بعدي & \multirow{2}{*}{ لنشاط مدرستتا } & \multirow{2}{*}{1} \\
\hline & & & $1, \cdot 1$ & $\cdot, \leqslant 0$ & & قبلى & & \\
\hline \multirow{2}{*}{$\cdot, .0$} & \multirow{2}{*}{$r \cdot, \cdot \varepsilon$} & \multirow{2}{*}{19} & T,IT & $7, \S 1$ & \multirow{2}{*}{$\mathrm{v}$} & بعدي & \multirow{2}{*}{ لنشاط كيف يتلوث } & \multirow{2}{*}{ r } \\
\hline & & & $1, Y$ & 1,07 & & قبلي & & \\
\hline \multirow{2}{*}{$\cdot, .0$} & \multirow{2}{*}{ Mr, } & \multirow{2}{*}{19} & $\cdot, \mathrm{\vee} \wedge$ & $V, 9 \leq$ & \multirow{2}{*}{9} & بعدي & \multirow{2}{*}{ لنشاط مدرستي } & \multirow{2}{*}{ r } \\
\hline & & & $\cdot, 91$ & $1, r \mu$ & & قبلى & & \\
\hline \multirow{2}{*}{$\cdot, .0$} & \multirow{2}{*}{$r r, \varepsilon)$} & \multirow{2}{*}{19} & $\cdot, \wedge \wedge$ & $\Lambda, 7)$ & \multirow{2}{*}{9} & بعدي & \multirow{2}{*}{ النشاط إندادة المخلفات } & \multirow{2}{*}{$\varepsilon$} \\
\hline & & & $\cdot, 7 \wedge$ & 1,91 & & قبلى ق ق ق ق ق ق & & \\
\hline \multirow{2}{*}{$\cdot, .0$} & \multirow{2}{*}{$r \varepsilon, \cdot r$} & \multirow{2}{*}{19} & $T, \cdot Y$ & 0,00 & \multirow{2}{*}{7} & بعدي & \multirow{2}{*}{ لنشاط تلوث الماء } & \multirow{2}{*}{0} \\
\hline & & &., $0 \leqslant$ & $r, \ldots$ & & قبلى & & \\
\hline \multirow{2}{*}{ مرتفع } & \multirow{2}{*}{$r \cdot, 071$} & \multirow{2}{*}{19} & $1, \cdot Y V$ & $r Y, V \mu$ & \multirow{2}{*}{ ry } & بعدي & \multirow{2}{*}{ الدرجة الكلية } & \\
\hline & & &., 97 & 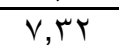 & & 1.9 & & \\
\hline
\end{tabular}

بحساب قيمة الـ (t test) بين درجات التلميذات في المجموعة التجريبية فى التطبيق

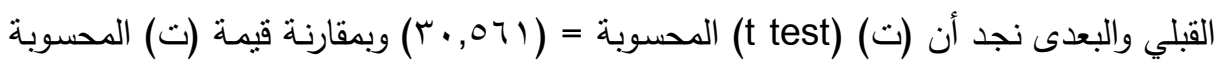
بقيمتى (ت) الجدوليتين عند درجة حريـة (^و) نجد أن قيمـة (ت) المحسوبة أكبر من قيمـة (ت) الجدولية عند مستوى (0. (. •) ).

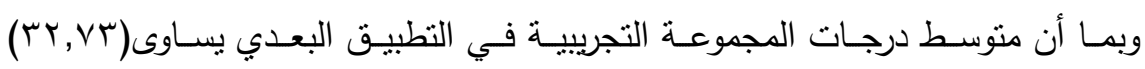

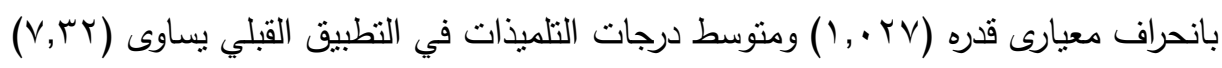

$$
\text { بانحراف معيارى قدره (97 (9 • ). }
$$

فنجد أن متوسط درجات التلميذات بالمجموعة التجريبية في التطبيق البعدي أعلى من

$$
\text { منوسط درجات التلميذات في التطبيق القبلي. }
$$

وهذه النتيجة تؤكد قبول الفرض الثالث الذي ينص على "توجد فروق دالة إحصائيًا بين

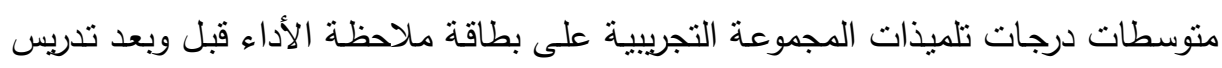
البرنامج المقترح لصالح التطبيق البعدي. 


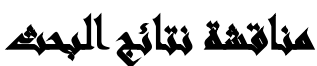

\section{من خلال إثبات تحقق فروض البحث وتحليل النتائج أمكن استخلاص الآتي:}

• أنشارت نتائج البحث الموضحة في جداول (0، و 7، \) إلى وجود فروق دالة إحصائياً بين

درجات التلميذات بالمرحلة المتوسطة بالمجموعة التجريبية في التطبيقين القبلي والبعدي لمقياس القيم البيئية، ومقياس المهارات البيئية الكلي، وكذلك في مكوناته الثلاثة (إدراك المشكلة البيئية وتحديدها، تتظيم البيانات وتحليلها، اقتراح الحلول للمشكلات البيئية) وكذللك بطاقة ملاحظة الأداء للمهارات البيئية؛ الأمر الذي يشير إلى فعالية البرنامج المقترح القائم على استراتيجية فكر ، زاوج، شارك. • كذللك أثنارت النتائج إلى فاعلية مواد المعالجة التجريبية التي أفادت نلميذات المجموعة المارت التجريبية في تتمية القيم البيئية، وإلى تدريس البرنامج القائم على استراتيجية فكر ، زاوج، شارك باستخدام أنشطة توضح القيم البيئية. • ويمكن إرجاع تللك النتائج أيضاً إلى الوسائل التعليمية التي تم استخدامها عند تدريس البرنامج من خلال ربط موضوعات البرنامج بالبيئة المدرسية وطبيعة المشكلات البيئية

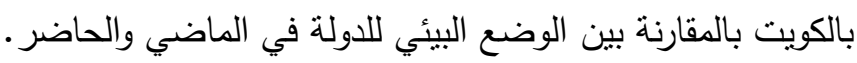

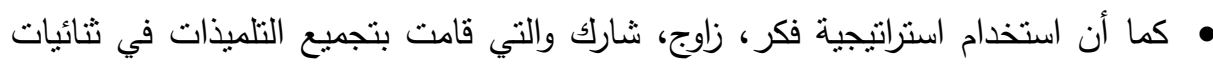

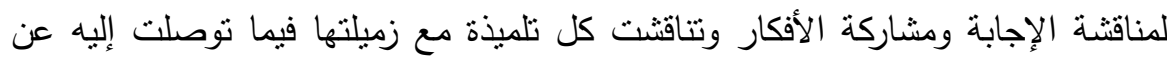
كل جزء في البرنامج يختلف عن الطريقة المعتادة في التعلم التقليدي، وتم ربط موضوعات ونئه ومشكلات البيئة الكوينية وبيئة التلميذات الحياتية، فترتب عليه إثارة انتباه التلميذات لكونها

أساليب غير نمطية حيث ساعد ذلك على تتمية القيم البيئية لمستوى الالتزام بالقيمة.

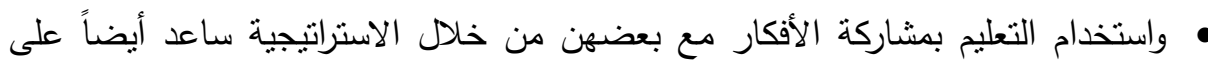
زيادة قدرة التلميذات على الفهم وعلى تطبيق ما تعلموه في حياتهم اليومية وإثارة دافعيتهم لممارسة أنشطة توضيح القيم البيئية وكذا استخدام الأنشطة الإثرائية وهذا بالطبع ساعد

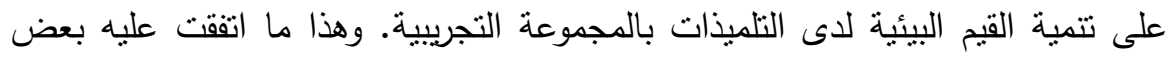

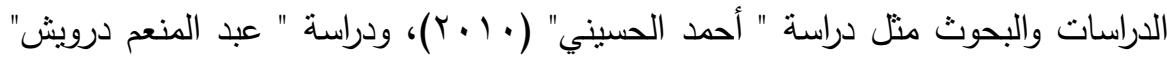

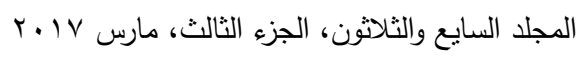




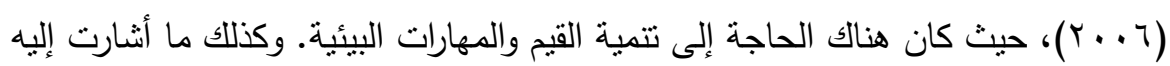

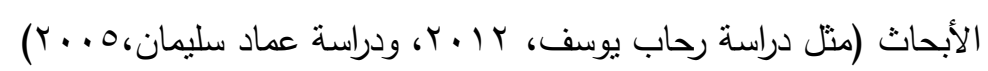
• وقد اتفقت نتائج البحث الحالي مع العديد من الدراسات والبحوث السابقة في فاعلية

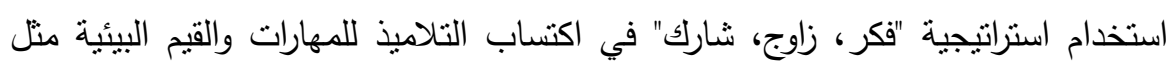

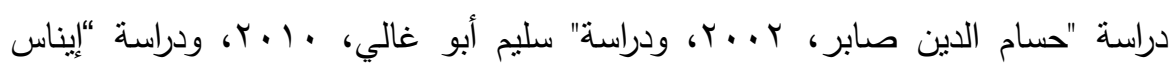

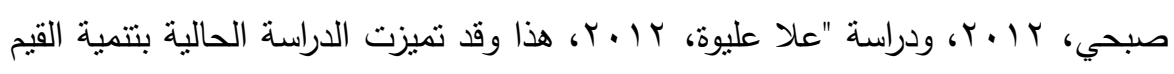

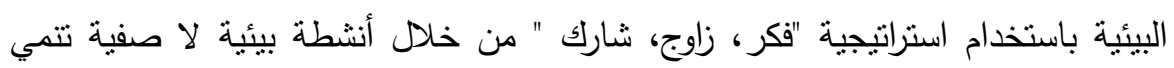

$$
\text { القيم البيئية والمهارات البيئية. }
$$

• يمكن إرجاع تفوق درجات الطلاب في التطبيق البعدي إلى تتظيم البرنامج في صورة

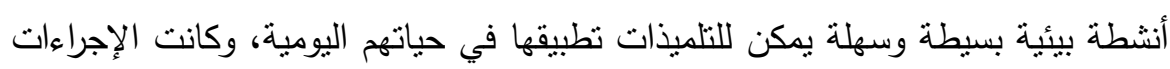

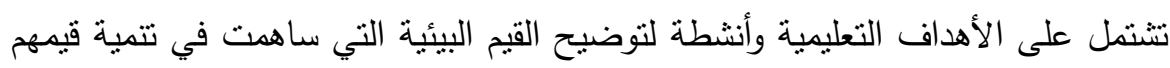

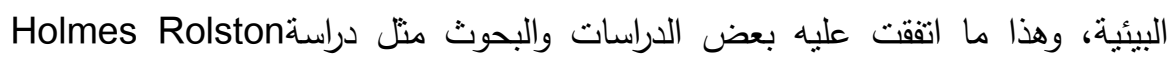

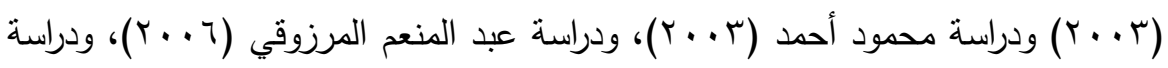

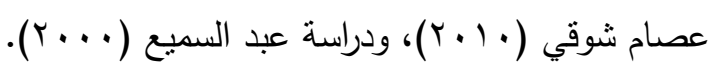

• استخدام استراتيجية "فكر ، زاوج، شارك" أتاح الفرص أمام التلميذات لتبادل الأفكار والآراء

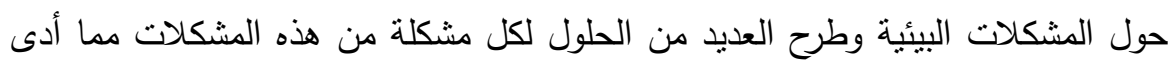
إلى تتمية القيم البيئية لاى التلميذات تجاه هذه المشكلات.

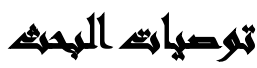

في إطار النتائج التي توصل إليها البحث يوصي بالآتي:

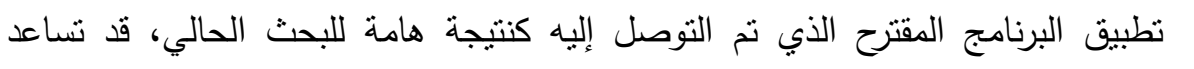
القائمين بالعملية التعليمة كي يساهم في تتمية القيم والمهارات البيئية لتلميذات المرحلة المتوسطة بدولة الكويت. تضمين مناهج المرحلة المنوسطة في دولة الكويت للقيم البيئية لتساعد التلميذات على بلى تتمية إحساسهن بالبيئة وكيفية التعامل معها بطريقة صحيحة.

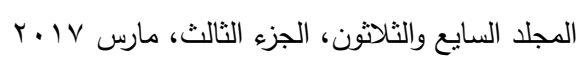


• تصميم وبناء الأنشطة البيئية التعليمية الممانلة في هذه المرحلة المتوسطة التي تتيح للتلميذات تتمية مهاراتهن الحياتية داخل وخارج المدرسة والمتضمنة لمحتوى البرنامج المئه المقترح.

• التأكيد على تضمين المناهج التعليمية بوزارة التربية في المراحل المختلفة لبعض المهارات

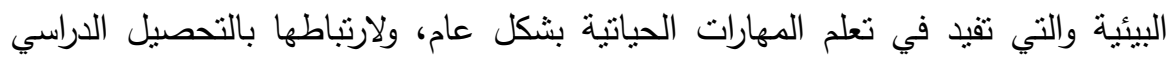
والاستفادة منها في الارتفاع بمستوى التحصيل.

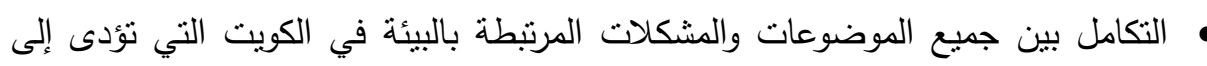
التكامل بين البيئة ودور التلميذات بالحفاظ على بيئاتهن ووطنهن.

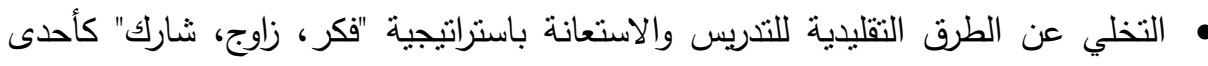

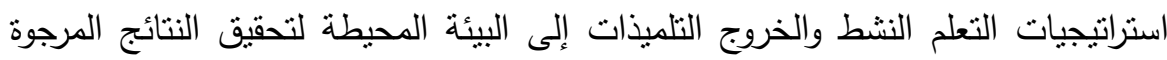

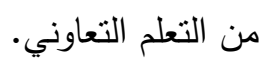

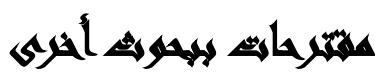

قد يثير هذا البحث إلى إجراء المزيل من الاراسـات والبحوث وثيقة الصلة بموضوع البحث لاستكمال ما بدأه البحث الحالي ومن هذه البحوث:

• برنامج مقترح قائم على استراتيجية فكر ، زاوج، شارك لتتمية المهارات البيئية تجاه حماية وتتمية البيئة الطبيعية في دولة الكويت.

• إجراء دراسات ميدانية أخري نهتم باستخدام نظرية التعلم بالملاحظة لتتمية القيم والمهارات البيئية والسلوك البيئي لدى التلاميذ في المراحل الدراسية المختلفة.

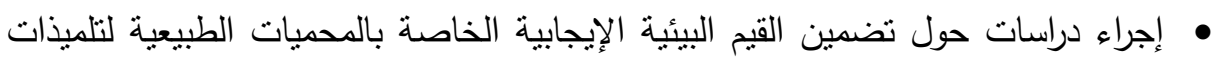
المرحلة المنوسطة لتتمية المسئولية البيئية لديهن. • دراسة للتعرف على أثر الأنشطة المدرسية في تتمية المهارات والاتجاهات البيئية لدى للى لئه تلاميذ المدارس الكوينية. 
إجراء دراسة ممانلة تهدف إلى تحليل المناهج والبرامج المقدة في وزارة التربية بشكل عام

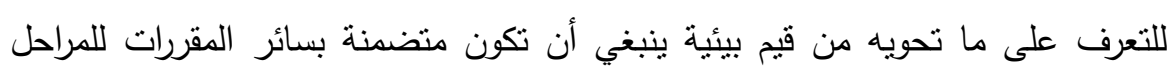

التعليمية المختلفة.

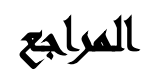

أحمد حسن اللقانى، فارعة حسن ( ( . ؟): مناهج التعليم بين الواقع والمستقبل، عالم الكتب، القاهرة

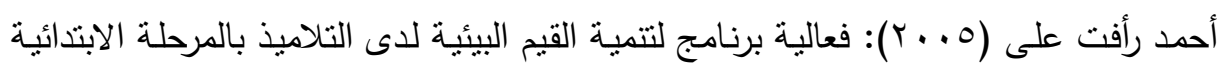

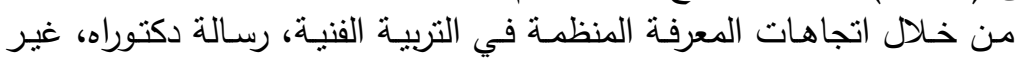

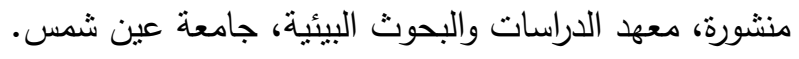

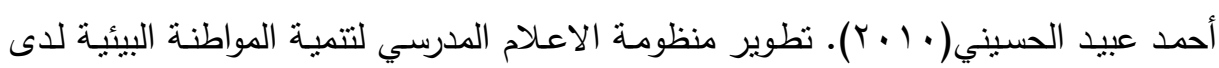

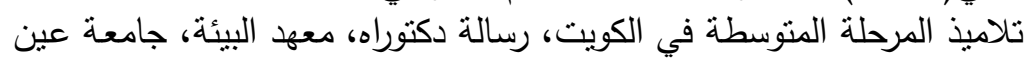

$$
\text { شمس. تلأن }
$$

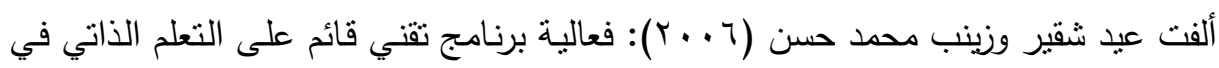

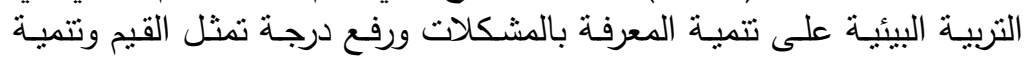

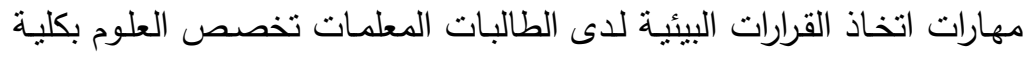

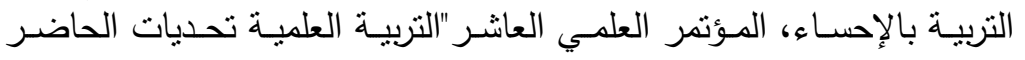

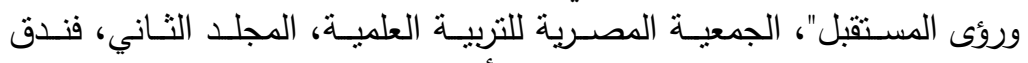

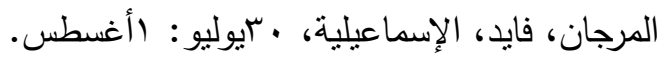

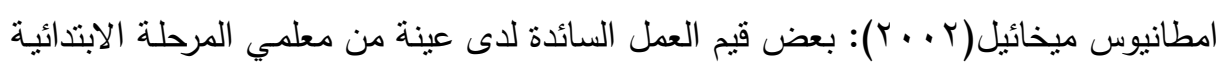

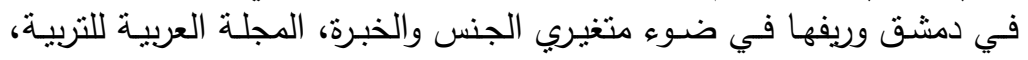
المنظمة العربية للتربية والثقافة والعلوم، يونية.

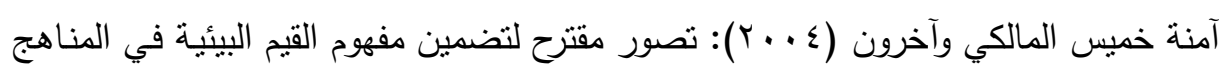

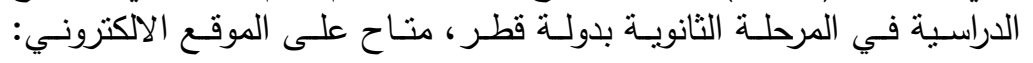
http://www.moe.edu.qa/Arabic/books/art9.2.shtml(Accesse

d February 11, 2009)

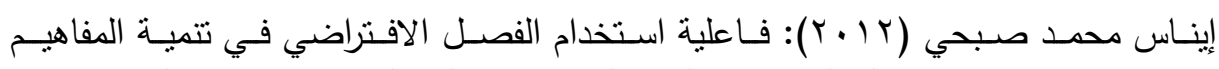

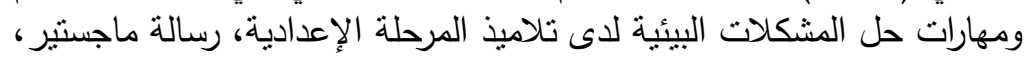

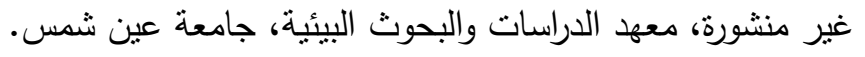

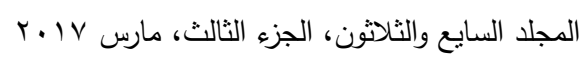




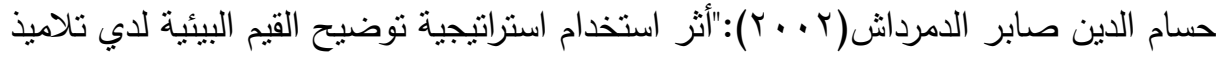

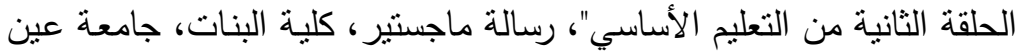

شمس.

حسن شحاتة (ب ץ): أساسيات التدريس الفعال في العالم العربي، دار المصرية اللبنانية،

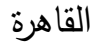

رحاب يوسف محمد السيد (r ب †): فاعلية برنامج في التربية البيئية لتلاميذ المرحلة الابتدائية

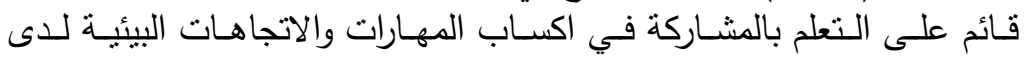
والديهم، رسالة دكتوراه، غير منشورة، معهد الدراسات والبحوث البيأية.

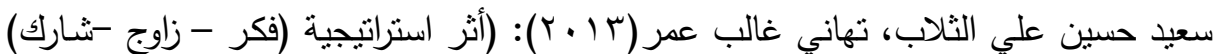

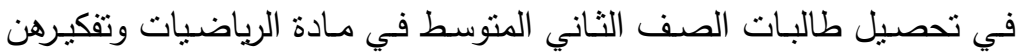
الاستدلالي - مجلة أداب الفراهيدي - جامعة الكويت.

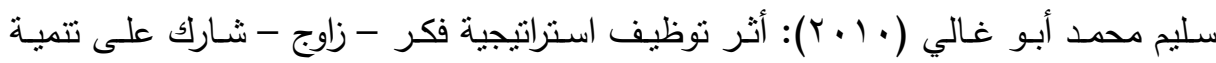

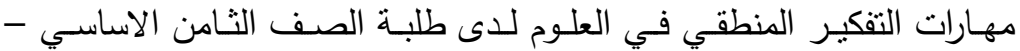

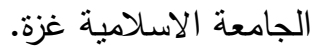

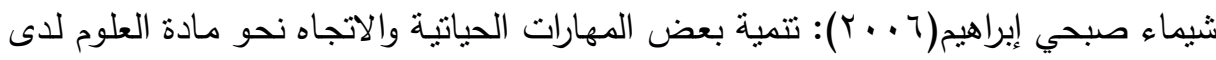

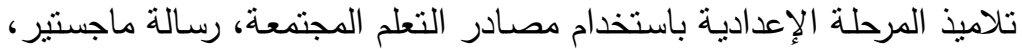
كلية التربية، جامعة عين شمس.

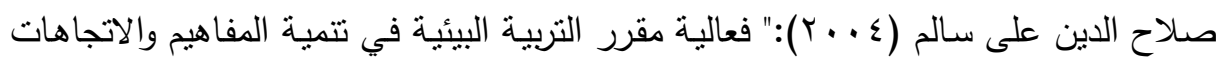

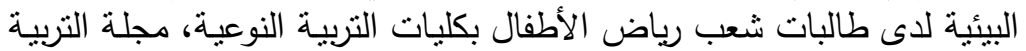

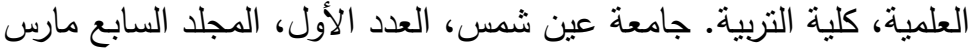

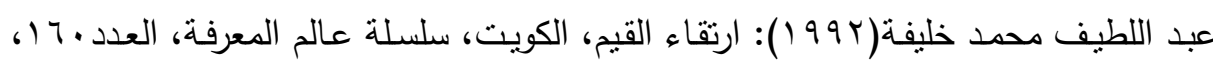
إبريل.

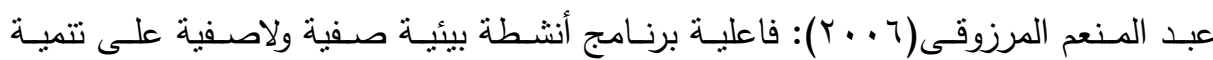

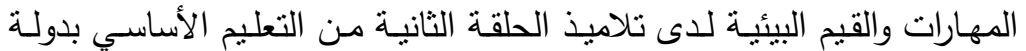
الإمارات العربية، رسالة دكتوراه غير منشورة، معهد الدراسات والبحوث البيأية، الباتية

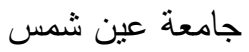




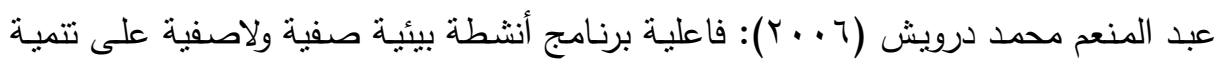

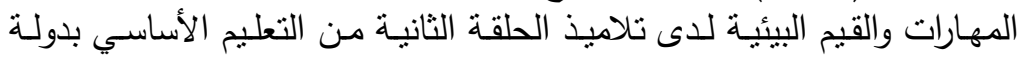
الإمـارات العربيـة المتحدة، رسـالة دكتوراه، غير منشورة، معهد البيئة، جامعـة الإنة

$$
\text { عين شمس. }
$$

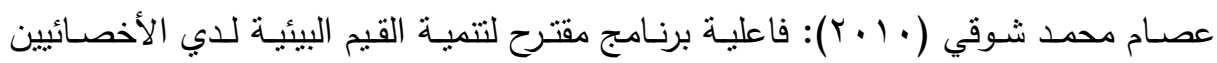
الاجتماعيين بمراكز الثباب يقوم على استراتيجيات تعليم القيم، رسالة دكتوراه، غير منشورة، معهد الدراسات والبحوث البيئية، جامعة عين شمس.

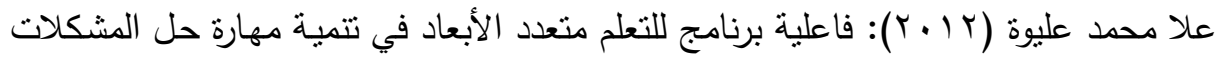

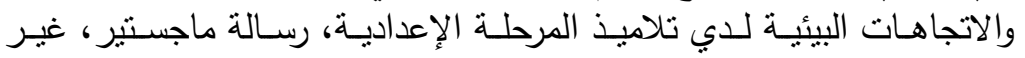

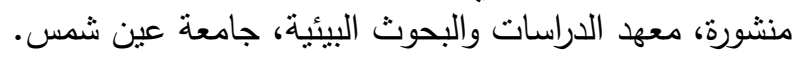

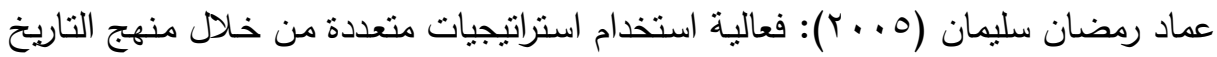

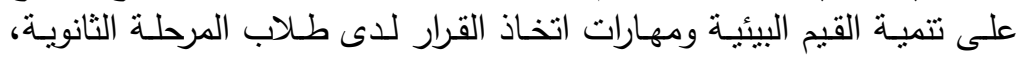

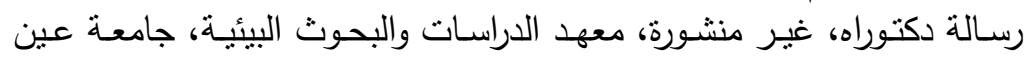

$$
\text { شمس. }
$$

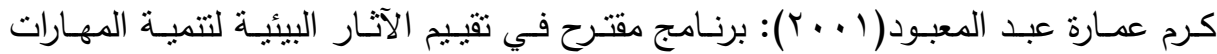

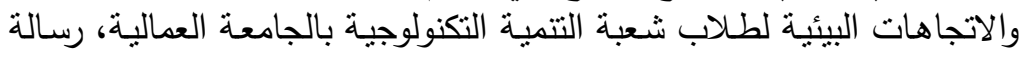

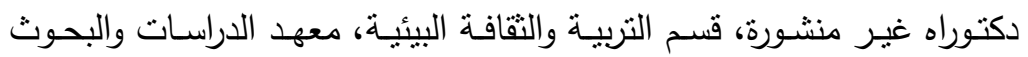

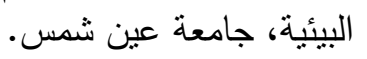

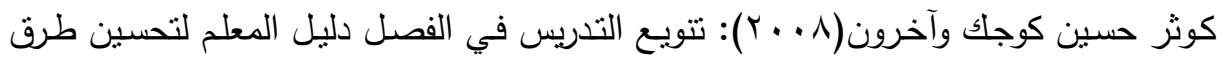

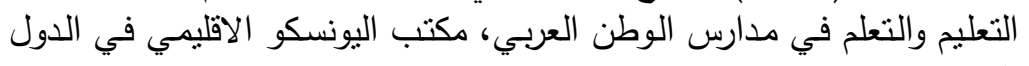

$$
\text { العربية بيروت. }
$$

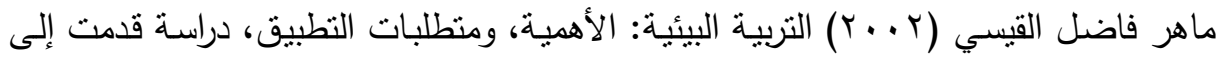

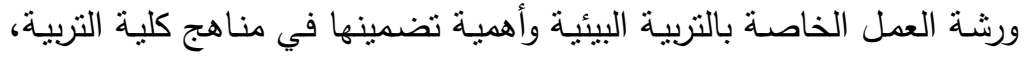
يوم البيئة العالمي،ه يونيو، مركز دراسات وعلوم البيئة، جامعة عدن.

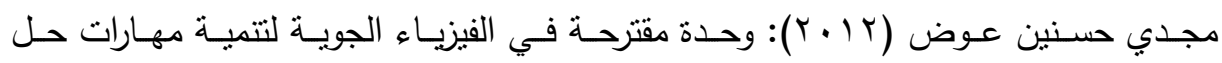

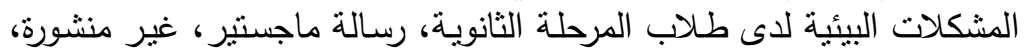
معهد الدراسات والبحوث البيئية، جامعة عين شمس. 


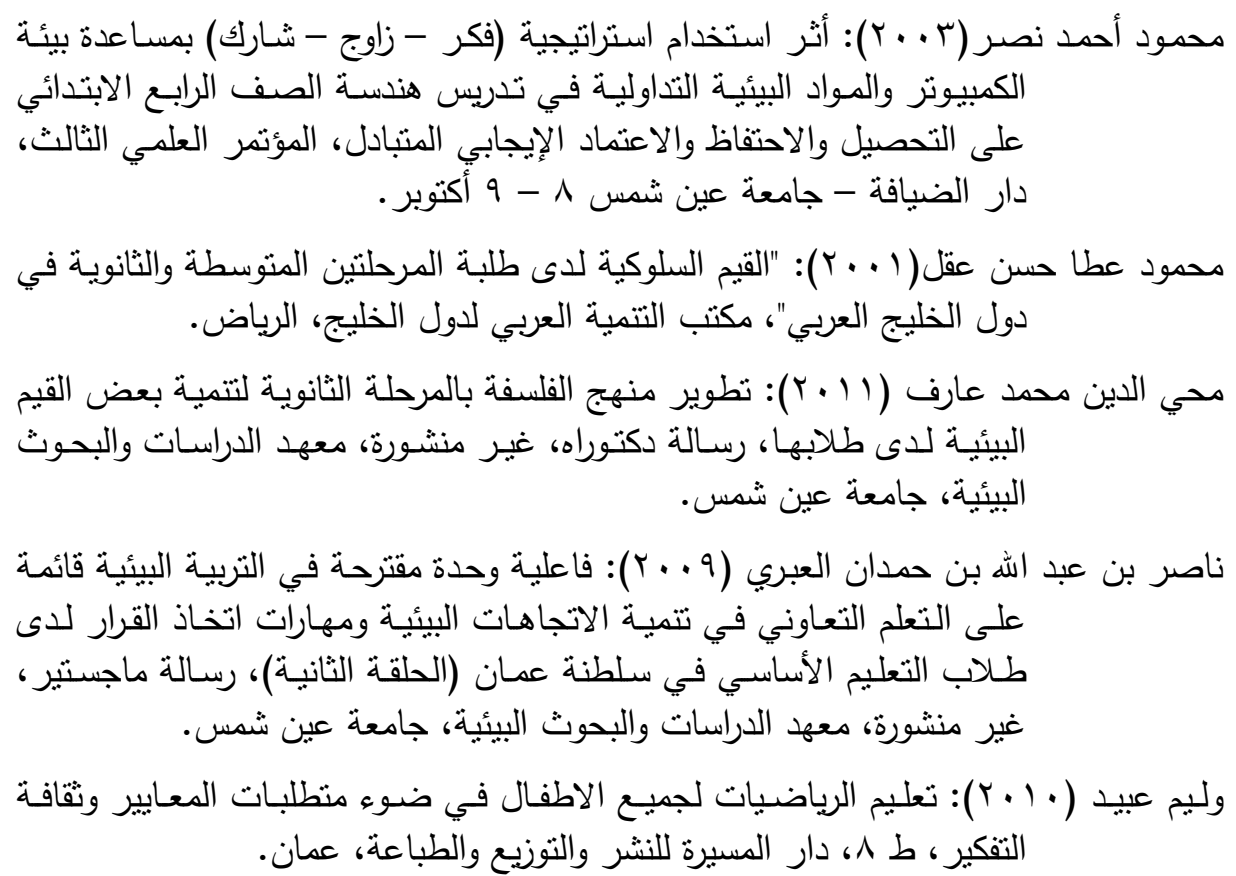

Bechtel, R. B. (1997). Values, believes and attitudes about the environment. In Environment \& behavior; An introduction Thousand Oaks, CA: Sage Publications. (pp. 107-128

Holmes

$$
\text { Rolston(2003) Values in nature, }
$$
www.fw.umn.edu/nres3011/valuein.html

Platte, Stephen A.(1991): "Cooperative Learning: A Practical Application Strategy", Journal of Social Education, v55 n5 p326-28, Sep. 1991.

Richard Baily, Eds,(2000); "Teaching values and citizenship across the curriculum", Kagan Page Limited, 2000,p.157. 
عبد المسيح سمعان عبد المسيح وآخرون

\title{
THE EFFECTIVENESS OF A PROGRAM BASED ON \\ STRATEGY OF (THINK - PAIR - SHARE) IN THE \\ DEVELOPMENT OF ENVIRONMENTAL VALUES \\ AND SKILLS OF MIDDLE STAGE PUPILS IN \\ KUWAIT
}

\author{
Abd Elmeseh, A. S. ${ }^{(1)}$; Alshaty, M. A. M. ${ }^{(2)}$ \\ and Al-Ajmi, Ghezaiyel, M. $^{(3)}$ \\ 1) Institute of Environmental Studies and Research, Ain Shams \\ University. 2) Counseling center behavioral and family, Kuwait 3) The \\ Ministry of Education, Kuwait
}

\begin{abstract}
The target of this Research is to develop environmental values and skills among middle school students through a program based on strategy (Think - Pair - Share). The State of Kuwait, the researchers have drawn up a list of environmental values and skills which students must develop middle school in Kuwait have been refereeing The following values were (1. savor the beauty of the natural environment 2-Kuwait environment clean without contaminating 3. valuing nature reserves 4-optimal use of environmental resources 5. valuation of the homeland and loyalty to him and his environment), and in light of the poll was prepared to see the current status of environmental values and skills in middle school It turns out it wasn't the intermediate address environmental values and skills sufficient to develop these values and environmental skills of students through activities provided for them. Thus, the researchers saw the need to develop a proposal based program strategy (think, pair, and share) for environmental values and skills development among pupils intermediate Kuwait. And which included 20 (20 active) Where he was relying on semi-experimental method per set (pre-posttest) as being the sixth grade pupils in Kuwait intermediate
\end{abstract}

$$
\text { المجلد السايع والثلاثون، الجزء الثالث، مارس V Y r. }
$$




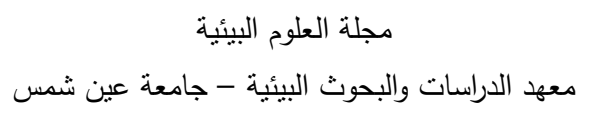

stage to the values scale and scale environmental skills before applying and after the program to measure the impact (of the proposed program) on the dependent variable (Environmental values and skills), The results were as follows:

There are significant differences between mean scores of tribal girls in the application and enforcement differences dimensional scale environmental values and skills for the benefit of the dimensional application at the 0.05 level. Which indicates that the impact of the program in the development of environmental values and skills to them. Research has recommended 